\title{
Overview of the field measurement campaign in Hyytiälä, August 2001 in the framework of the EU project OSOA
}

\author{
M. Boy ${ }^{1}$, T. Petäjä ${ }^{1}$, M. Dal Maso ${ }^{1}$, Ü. Rannik ${ }^{1}$, J. Rinne ${ }^{1}$, P. Aalto ${ }^{1}$, A. Laaksonen ${ }^{2}$, P. Vaattovaara ${ }^{2}$, J. Joutsensaari ${ }^{2}$, \\ T. Hoffmann ${ }^{3}$, J. Warnke ${ }^{3}$, M. Apostolaki ${ }^{4}$, E. G. Stephanou ${ }^{4}$, M. Tsapakis ${ }^{4}$, A. Kouvarakis ${ }^{4}$, C. Pio ${ }^{5}$, A. Carvalho ${ }^{5}$, \\ A. Römpp ${ }^{6}$, G. Moortgat ${ }^{6}$, C. Spirig ${ }^{7}$, A. Guenther ${ }^{7}$, J. Greenberg ${ }^{7}$, P. Ciccioli ${ }^{8}$, and M. Kulmala ${ }^{1}$ \\ ${ }^{1}$ Dept. of Physical Sciences, University of Helsinki, P.O. Box 64, FIN-00014, Finland \\ ${ }^{2}$ University of Kuopio, Kuopio, Finland \\ ${ }^{3}$ Institut für Specktrochemie, Dortmund, Germany \\ ${ }^{4}$ Environmental Chemical Processes Laboratory - School of Sciences and Engineering-University of Crete, GR-71409 \\ Heraklion, Greece \\ ${ }^{5}$ Universidade de Aveiro, Departamento de Ambiente e Ordenamento, Portugal \\ ${ }^{6}$ Max-Planck-Institut für Chemie, Atmospheric Chemistry Division, D-55020, Germany \\ ${ }^{7}$ Atmospheric Chemistry Division, National Centre for Atmospheric Research, Boulder, CO, USA \\ ${ }^{8}$ Instituto di Metodologie Chimiche, Area della Ricerca del CNR di Montelibretti, Italy
}

Received: 10 April 2003 - Published in Atmos. Chem. Phys. Discuss.: 11 July 2003

Revised: 16 March 2004 - Accepted: 13 April 2004 - Published: 27 April 2004

\begin{abstract}
As part of the OSOA (Origin and formation of Secondary Organic Aerosols) project, two intensive field campaigns were conducted in Melpitz, Germany and Hyytiälä, Finland. This paper gives an overview of the measurements made during the Hyytiälä campaign, which was held between 1 and 16 August 2001. Various instrumental techniques were used to achieve physical and chemical characterisation of aerosols and to investigate possible precursor gases.
\end{abstract}

During the OSOA campaign in Hyytiälä, particle formation was observed on three consecutive days at the beginning of the campaign (1 to 3 August 2001) and on three days later on. The investigation of the meteorological situation divided the campaign into two parts. During the first three days of August, relatively cold and clean air masses from northwest passed over the station (condensation sink $-\mathrm{CS}:<0.002 \mathrm{~s}^{-1}$, $\mathrm{NO}_{\mathrm{x}}:<0.5 \mathrm{ppb}$ ). Daily particle bursts of one fraction of the nucleation mode aerosols $(3-10 \mathrm{~nm})$ with number concentrations between $600-1200$ particles $\mathrm{cm}^{-3}$ were observed. After this period, warmer and more polluted air from south-west to south-east arrived at the station (CS: $0.002-0.01 \mathrm{~s}^{-1}, \mathrm{NO}_{\mathrm{x}}$ : $0.5-4 \mathrm{ppb}$ ) and during these 13 days only three events were observed. These events were not as apparent as those that occurred during the earlier period of the campaign. The chemical analyses from different institutes of $\mathrm{PM}_{2}, \mathrm{PM}_{2.5}$ and $\mathrm{PM}_{10}$ particles confirmed the assumption that organic mat- ter from the oxidation of various terpenes contributed to the formation of secondary organic aerosols (SOA). Concerning these conclusions among others, the ratio between formic (oxidation product of isoprene and monoterpenes by ozone) and acetic acid (increased by anthropogenic emissions) (ratio $=1$ to 1.5 ) and concentration of different carboxylic acids (up to $62 \mathrm{ng} \mathrm{m}^{-3}$ ) were investigated. Gas/particle partitioning of five photo-oxidation products from $\alpha$ - and $\beta$-pinene resulted in higher concentrations of pinonic, nor pinonic and pinic acids in the particle phase than in the gas phase, which indicates a preference to the particle phase for these compounds. The average growth factors (GF) from $100 \mathrm{~nm}$ particles in water vapour gave a diurnal pattern with a maximum during daytime and values between 1.2 and 1.7. On average, the amount of secondary organic carbon reached values around $19 \%$ of the sampled aerosols and we speculate that formation of SOA with the influence of photooxidation products from terpenes was the reason for the observed particle bursts during the campaign. However, correlations between the precursor gases or the favourable condensing species with the monitored nucleation mode particles were not found. For the investigated time period other factors like the condensation sink of newly formed particles to the pre-existing aerosols, temperature and solar irradiance seem to be more important steering parameters for the production of new aerosols.

Correspondence to: $\mathrm{M}$. Boy

(michael.boy@helsinki.fi) 
Another open question concerns the vertical distribution of the formation of SOA. For this reason measurements were conducted at different altitudes using a tethered balloon platform with particle sampling and particle counting equipment. They were incorporated with eddy covariance (EC) flux measurements made at $23 \mathrm{~m}$ above ground level. The results give first indications that production of new aerosols happens throughout the planetary boundary layer (PBL), whereby different parameters e.g. temperature, CS, solar irradiance or concentration of monoterpenes are responsible for the location of the vertical maximum.

\section{Introduction}

The purpose of the EU project OSOA (Origin and Formation of Secondary Organic Aerosols) was to quantitatively understand the sources and formation mechanisms of secondary organic aerosols by applying a combination of laboratory studies, chemical analysis of particulate matter, modelling and field observations. Within the framework of this project an extensive field campaign was carried out in Hyytiälä, Finland between 1 and 16 August 2001. Altogether eight institutes from five different countries participated in this experiment with some newly developed analytical instrumentation and methodologies to reach a better scientific knowledge of the sources, physical properties and chemical composition of this organic fraction of atmospheric aerosols.

It is known that the total organic carbon can comprise 25$65 \%$ of the fine aerosol (diameter $<2.5 \mu \mathrm{m}$ ) mass in some regions (Chow et al., 1994; Novakov et al., 1997) and that the emission by vegetation of volatile organic compounds (VOC) is approximately $1150 \mathrm{C} \mathrm{Tg}$ per year (Guenther et al., 1995). Furthermore, we know that bursts of newly formed aerosols appear in various rural areas (i.e. continental boundary layer: Kavouras et al., 1998; Kulmala et al., 2001a; Nilsson et al., 2001a; Birmili et al., 2002). However, the exact understanding of the pathways from emission of VOCs to the particulate phase still includes far too many unknowns to draw final conclusions.

Secondary organic aerosols are formed, when the saturation vapour pressure of the gas-phase oxidation products is sufficiently low so that these species can condense on pre-existing particles or even form new particles through homogeneous nucleation. Hoppel et al. (2001) observed in Calspan's $600 \mathrm{~m}^{3}$ environmental chamber aerosol formation and growth from the reaction products of $\alpha$-pinene and ozone, utilizing relatively low mixing ratios of $\alpha$ pinene (15 ppb) and ozone (100 ppb). Nucleation in this $\alpha$ pinene/ozone system could not be explained by classical nucleation theory. The authors suggested that the nucleation rate in the $\alpha$-pinene/ozone system may be limited by the initial nucleation steps (i.e. dimer, trimer or adduct formation). This would be a possible pathway how organic species formed out of gas-phase reactions from monoterpenes could contribute to the formation of new aerosols by homogeneous nucleation. However, the mixing ratios of $\alpha$-pinene used in this experiment are still one order of magnitude higher than observed e.g. in a rural area of central Finland. Another theory, which would explain the nucleation events or the time of particle bursts, is ternary nucleation of $\mathrm{H}_{2} \mathrm{O}, \mathrm{NH}_{3}$ and $\mathrm{H}_{2} \mathrm{SO}_{4}$ (Korhonen et al., 1999). According to the suggestions of Kulmala et al. (2000), ternary nucleation can occur at typical tropospheric conditions leading to a reservoir of thermodynamically stable clusters (TSCs, diameter $\cong 1 \mathrm{~nm}$ ), which under certain conditions grow to detectable sizes. In this case organic compounds with low volatility could be the condensing species, which bring the particles to the size of $3 \mathrm{~nm}$ in diameter, where present state-of-art instrumentation can detect them.

The aim of the OSOA project and the field campaign in Hyytiälä was to get more detailed information about the precursor gases, condensing species and reaction mechanisms involved in the formation process of secondary organic aerosols. Out of these reasons, gas-phase and particle phase measurements were carried out in a rural area with low anthropogenic impact.

\section{Instrumentation}

\subsection{SMEAR II}

Data were collected at the Station for Measuring Forest Ecosystem-Atmosphere Relations (SMEAR II) in Hyytiälä, Finland. The station is located in Southern Finland $\left(61^{\circ} 51^{\prime} \mathrm{N}, 24^{\circ} 17^{\prime} \mathrm{E}, 181 \mathrm{~m}\right.$ asl), with extended areas of Scots Pine (Pinus sylvestris) dominated forests. The conditions at the site are typical for a background location; however, occasionally measurements were polluted by the station buildings $(0.5 \mathrm{~km}$ away) and the city of Tampere (60 km away) both located in a west-south-west direction $\left(215-265^{\circ}\right)$ from the instruments.

A Differential Mobility Particle Sizer (DMPS) system (located in the cottage) monitored aerosol size distributions at $2 \mathrm{~m}$ height from ground level. This gave a continuous view of the distribution and evolution of sub-micrometer aerosol particles. The DMPS system used here actually consists of two systems. The first system includes a TSI 3025 UFCPC and a Hauke-type short DMA (Differential Mobility Analyzer) and measured particles between 3 and $20 \mathrm{~nm}$ in dry diameter. The second system included a TSI 3010 CPC and a Hauketype medium DMA capable of measuring particles between 20 and $500 \mathrm{~nm}$. A particle size distribution is recorded every $10 \mathrm{~min}$ (Aalto et al., 2001).

Concentrations of $\mathrm{H}_{2} \mathrm{O}, \mathrm{NO}_{\mathrm{x}}, \mathrm{SO}_{2}$ and $\mathrm{O}_{3}$ were measured with an URAS gas analyzer, chemiluminescence gas analyzer (TEI 42S), fluorescence analyzer (TEI 43BS) and an ozone analyser (API 400), respectively. Air samples were 
collected from the mast at $4.2 \mathrm{~m}, 16.8 \mathrm{~m}$ and $67.2 \mathrm{~m}$ height levels every $5 \mathrm{~min}$. Temperature (measured with PT-100sensors, platinum resistance thermometers) and horizontal wind speed (measured with cup anemometers) were collected every $50 \mathrm{~s}$ at these three heights as well. Wind direction was measured every $50 \mathrm{~s}$ by wind vanes at $16.8 \mathrm{~m}$ and $50.4 \mathrm{~m}$ heights.

A Sensitron AB monostatic $2.3 \mathrm{kHz}$ doppler Sound Detection and Ranging system (SODAR) was used to measure the stability of the air (echo strength) and the means and standard deviations of the horizontal and vertical wind components as well as wind direction up to a height of $500 \mathrm{~m}$ in $25 \mathrm{~m}$ intervals. Raw echo measurements were achieved in 8$\mathrm{s}$ cycles between three antennas. The vertical antenna echo strength was averaged and stored every $3 \mathrm{~min}$. Averages and standard deviations of wind speed were then derived and averaged over $30 \mathrm{~min}$ periods.

Spectral solar irradiance in the range from 280 to $580 \mathrm{~nm}$ and a step width of $1 \mathrm{~nm}$ was measured with a Bentham DM150 double monochromator. The scans were performed every half hour and lasted approximately $11 \mathrm{~min}$. A detailed description of this instrument is given by Boy and Kulmala (2002a).

The aerosol particle number fluxes were measured by the eddy covariance (EC) technique at a height of $23 \mathrm{~m}$, approximately $10 \mathrm{~m}$ above the forest canopy. The fast response measurements $(20 \mathrm{~Hz})$ of wind speed and particle number concentration were performed by a sonic anemometer (Solent Research R3, Gill Instruments, Lymington, UK) and a modified condensational particle counter (CPC) TSI model 3010 (TSI Incorporated, Shoreview, MN, USA). The particle sizes detected by the EC system included particles in the range of 10 to $500 \mathrm{~nm}$. Lower cut-off size $(50 \%$ counting efficiency) for the CPC was determined as $14 \mathrm{~nm}$ by Buzorius et al. (2001). Particle fluxes were calculated for half-hour averaging periods. More details of the particle eddy covariance system and various aspects of its application and operation can be found in Buzorius et al. (2000).

For a more detailed description of the SMEAR II station and instrumentation, see Kulmala et al. (2001a) and www. honeybee.helsinki.fi/smear/.

\subsection{HTDMA and OTDMA}

As a part of the physicochemical characterization of aerosol during the Hyytiälä campaign, hygroscopic properties of sub-micron particles as well as their ability to absorb ethanol were monitored using Hygroscopicity and Organic Tandem Differential Mobility Analyzers (HTDMA and OTDMA). They were set up in a container close to the mast and they used the same sample inlet, which drew air from a height of $16 \mathrm{~m}$ through a steel tube (diameter $2.5 \mathrm{~cm}$ ). The flow rate was approximately $17 \mathrm{~L} \mathrm{~min}^{-1}$ in order to minimize particle losses due to a long residence time inside the inlet tube. The samples were drawn through $10 \mathrm{~mm}$ OD copper tubes from the main inlet line near the container to the individual instruments.

The HTDMA system consists of two Vienna type DMAs (Winklmayr et al., 1991) in series and one TSI-CPC 3010 particle counter for concentration measurements. In addition there is also a humidification unit, which generates the desired relative humidity inside the second DMA in two stages. Sheath air and aerosol sample flow are humidified separately. The system is built following the guidelines set by Hämeri et al. (2000) to measure also in the ultra-fine size range (10$20 \mathrm{~nm}$ ). As an output, the HTDMA gives the ratio of particle diameter at elevated $\mathrm{RH}$ to that at dry conditions, denoted as growth factor (GF).

The hygroscopicity measurements of the particles were conducted at $\sim 90 \% \pm 4 \%$ relative humidity. Size changes in elevated relative humidity were monitored for the particles of 20,30,50, 100 and $150 \mathrm{~nm}$ in diameter. Concentrations in the HTDMA were not corrected with respect to losses inside the system and sampling inlet. Fluctuations of RH during the measurements were not taken into account either. The functionality of the HTDMA was checked daily by measuring the growth factor for a known substance, pure ammonium sulphate aerosol. It was generated from liquid solution with a TSI 3076 Constant Output Atomizer. Hygroscopicity data was obtained every $10 \mathrm{~min}$ for one dry size. Taking into account the number of dry sizes measured, hygroscopic properties were measured ca. once per hour for each dry size. The HTDMA was in operation continuously.

The main features of the OTDMA are similar to those of the HTDMA with the exception that the humidification unit is used to generate a constant ethanol saturation ratio inside the second DMA. The details of the instrument and interpretation of the OTDMA data are described in Joutsensaari et al. (2001). Ethanol was chosen as organic solvent because 1) it dissolves a wide range of organic compounds, and does not dissolve most inorganic salts, 2) there's a lot of data of the ethanol solubility of different materials in the literature and 3) it is fairly convenient to use in practice, i.e. there's no danger of explosion, it is not toxic, and its vapour pressure is manageable. Growth of aerosol particles in ethanol vapour depends on composition of the particles. Particles can be roughly classified based on their growth in ethanol vapour: a high GF indicates that particles are composed of well ethanol soluble material(s), very probably organic, whereas a low GF indicates that particles are composed of material(s) that do not have a very high ethanol solubility (could be organic) or partly of ethanol insoluble and partly of ethanol soluble material(s). Ethanol insoluble materials include elementary carbon, minerals, most inorganic salts and also different organics.

In most of the experiments, aerosol particles were only treated inside DMA-2 by ethanol-rich sheath air and no aerosol treatment was used before DMA-2. In this paper, only results without aerosol treatment before DMA-2 are presented. Growth in ethanol vapour was mainly determined for 
Table 1. Data collected on tethered balloons at Hyytiälä during the OSOA campaign 2001.

\begin{tabular}{|c|c|c|c|c|c|}
\hline Date & VOC profiles & integrative $\mathrm{VOC}$ & OPC profiles & CPC profiles & $\begin{array}{c}\text { Met. Profiles } \\
\text { (Temp./RH) }\end{array}$ \\
\hline 2 Aug. & 1 & & 2 & & 3 \\
\hline 3 Aug. & 4 & 4 & 8 & & 8 \\
\hline 4 Aug. & & 2 & 6 & & 6 \\
\hline 5 Aug. & 2 & 3 & 4 & & \\
\hline 6 Aug. & 2 & 1 & 6 & & \\
\hline 7 Aug. & 3 & 3 & 6 & 2 & \\
\hline 8 Aug. & 3 & 4 & 8 & 8 & \\
\hline 9 Aug. & 2 & 1 & 8 & 6 & \\
\hline 10 Aug. & & & & & 4 \\
\hline 12 Aug. & 3 & 2 & & 10 & \\
\hline Total & 20 & 20 & 48 & 26 & 76 \\
\hline
\end{tabular}

particles of 20,30, 50, 80 and $100 \mathrm{~nm}$ in diameter. Saturation ratio (S) of ethanol vapour was kept at $0.90 \pm 0.02$ during the experiments. The OTDMA measurements were mainly carried out during daytime ( 9 a.m. -8 p.m.) because the system is not fully automatized and supervision is needed during measurements. During daytime of the campaign, OTDMA results were obtained for 6 event (1, 2, 3, 7, 10 and 14 August) and 10 non-event days. Only a few nighttime experiments (15, 16 and 17 August) were carried out.

Atmospheric aerosol is often an external mixture, i.e. it consists of particles which have different chemical compositions. Their water and ethanol uptake properties may therefore vary, which are observed in the HTDMA and OTDMA as distinct peaks.

\subsection{Tethered balloon platform measurements}

Measurements on tethered balloon platforms can be used to derive gas fluxes averaged over large areas $\left(20\right.$ to $\left.<200 \mathrm{~km}^{2}\right)$ (Davis et al., 1994; Greenberg et al., 1999; Helmig et al., 1998). For this purpose, two tethered helium balloons (Vol.: $9 \mathrm{~m}^{3}$, Blimp Works, Statesville, NC) were flown at heights between $2 \mathrm{~m}$ and $1.2 \mathrm{~km}$ above ground during the field campaign in Hyytiälä. The launch site was the soccer field at the Hyytiälä station, located $0.9 \mathrm{~km}$ southeast of the SMEAR II mast.

VOCs were collected onto adsorbent cartridges (combinations of Carbotrap ${ }^{\circledR}$, and Carbosieve S-III ${ }^{\circledR}$ ) by miniaturized air samplers. The sampling packages also include sensors for temperature and pressure measurements, and can be attached to any position on the tether line. Details about these samplers are given in Greenberg et al. (1999). Analysis of VOC samples was performed in the laboratory at NCAR (Boulder, $\mathrm{CO}$ ), with gas chromatography and mass spectrometry detection (GC-MS). The procedure for the analysis of the cartridges is described by Greenberg et al. (1995).
In addition to VOC sampling, in-situ particle counters were attached to the tethered balloons. Two handheld particle counters were used, an optical particle counter (OPC) (ABACUS, Particle Measurement Systems, Boulder, CO) and a condensation particle counter (CPC) (Model 3007, TSI Inc., Shoreview, MN). The OPC quantifies particle number concentrations in 4 size bins $(0.3-0.5 \mu \mathrm{m}, 0.5-1 \mu \mathrm{m}, 1-5 \mu \mathrm{m}$, and $>5 \mu \mathrm{m}$ diameter), the CPC measures the total particle number in the size range of $10 \mathrm{~nm}-1 \mu \mathrm{m}$. According to calibration measurements by Hämeri et al. (2002) the 50\% detection efficiency for the CPC was $10 \mathrm{~nm}$.

Tethered balloons were flown during daytime from $2 \mathrm{Au}-$ gust to 12 August, in two basic configurations.

1. VOC sampling package and particle sensor attached $0.5 \mathrm{~m}$ below the balloon with continuous measurements during ascent and descent. This setup generates vertical profiles of temperature, humidity and particles, as well as an integrative VOC measurement from ground to the maximum height of the balloon. With time resolutions of $30 \mathrm{~s}$ (OPC), $10 \mathrm{~s}$ (CPC, averaged data of originally $1 \mathrm{~Hz}$ ) and $2 \mathrm{~s}$ (temperature and humidity) at ascent and descent rates of $0.5-1 \mathrm{~m} \mathrm{~s}^{-1}$, the resulting vertical resolutions were 30 and $10 \mathrm{~m}$ for particle measurements and $1-2 \mathrm{~m}$ for meteorological data, respectively.

2. Three VOC sampling packages attached on the tether line at heights of about 120,250 and $550 \mathrm{~m}$. The packages sampled air at those heights during $30 \mathrm{~min}$, delivering a mean VOC vertical profile of the lowest $550 \mathrm{~m}$.

Measuring on tethered balloons was limited by weather conditions. Rain and high wind speeds prevent a safe operation and reduced the data coverage during the OSOA campaign. A total of 48 successful balloon flights were performed as summarized in Table 1. 

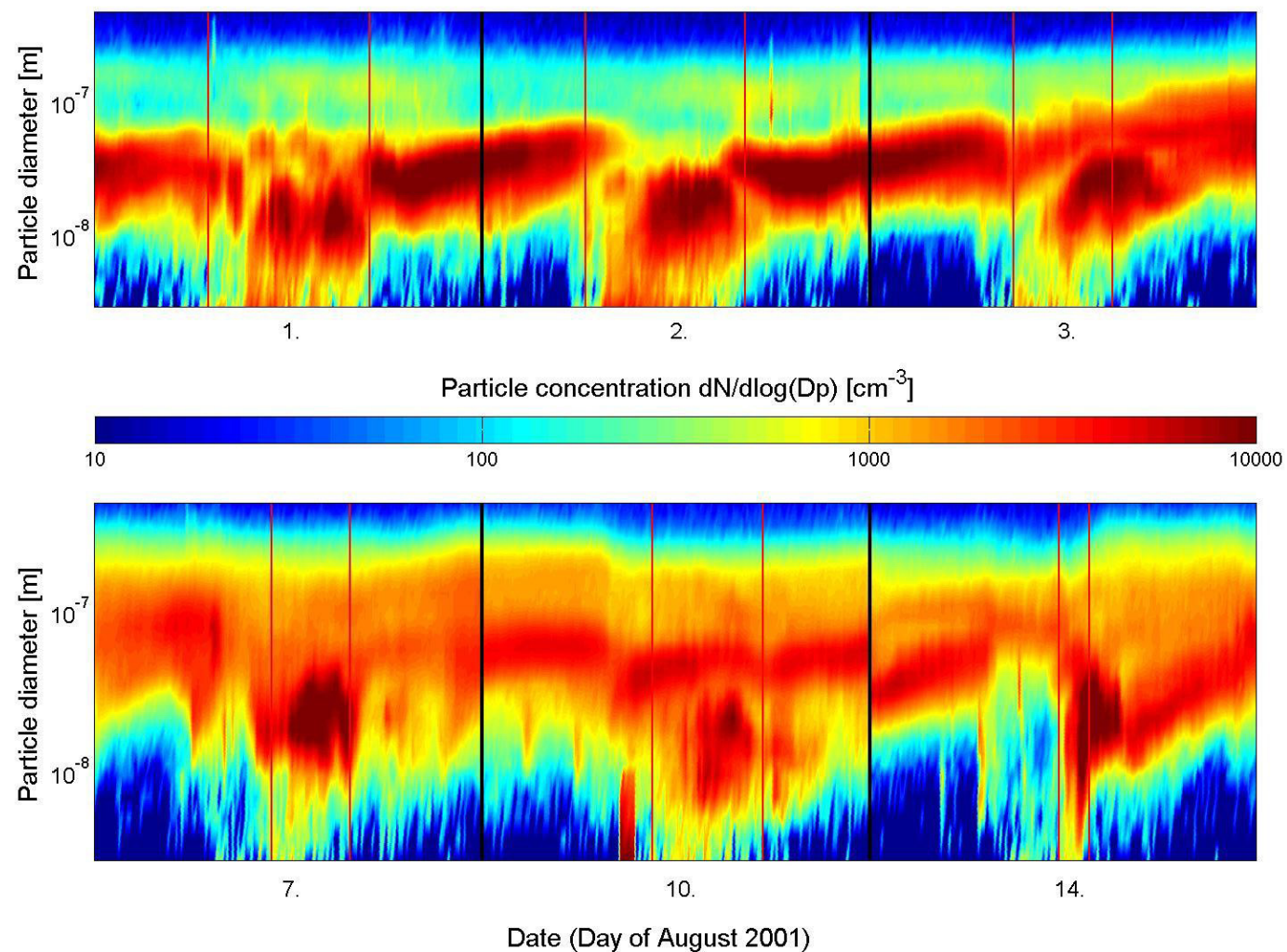

Fig. 1. Aerosol number size distributions from the DMPS system at $2 \mathrm{~m}$ height in Hyytiälä, Finland for all the event days during the OSOA field campaign. Included as thin red lines are the start and end times of the particle bursts (times: $\left[\mathrm{N}_{3}-10 \mathrm{~nm}\right]>\mathrm{or}_{<2} 200 \mathrm{particles} \mathrm{cm}^{-3}$ ).

All gas and particle samples described below were taken on an extra tower approximately $15 \mathrm{~m}$ away from the mast at a height of $16 \mathrm{~m}$ ( $2 \mathrm{~m}$ above the canopy).

2.4 Collection of formic and acetic acids with an annular denuder system

Formic and acetic acid were collected over $12 \mathrm{~h}$ periods, day and night, using an annular denuder system with DNPHcoated cartridges and an efficiency of $97 \%$. The denuders were extracted using ultra-pure water, and the extract was analysed by isocratic ion chromatography (Lawrence and Koutrakis, 1994; Zervas et al., 1999). Gaseous carbonyls were collected during $12 \mathrm{~h}$ periods (day and night) by drawing air through (DNPH)-coated Sep-Pak silica cartridges (Waters Assay Milford), (Sirju and Shepson, 1995), after removal of ozone in a KI impregnated copper tube coil. The cartridges were extracted with acetonitrile and the extract was analysed by binary gradient HPLC with diode-array detection. Parallel measurements of gaseous formic and acetic acids were also performed by using an annual denuder equipped with a filter pack system (Lawrence and Koutrakis, 1996). The analyses of the denuder extracts were performed by ion chromatography (Mihalopoulos et al., 1997).
2.5 Gas- and particle-phase collection of monoterpene photo-oxidation products

Carbonaceous aerosol were sampled, using a novel device allowing simultaneous collection of gas and particle associated polar photo-oxidation products of monoterpenes (Kavouras et al., 1999a), for 12-h sampling periods from 31 July to 8 August 2001 in the forest. Details for the sampling device and sampling procedures are given in Kavouras et al. (1999b). The polar and acidic fractions of all samples were analysed according to Kavouras et al. (1999b) using a GCQ Finnigan ion trap gas chromatograph-mass spectrometer.

2.6 High-volume sampling of organic aerosols and analysis by thermal-optical method and GC/MS

The particulate matter collection was carried out by means of high-volume samplers, on Whatman QMA quartz filters. Both size segregated and non-segregated samples were obtained. A fraction of each aerosol sample was analysed for black and organic carbon $(\mathrm{BC}$ and $\mathrm{OC}$, respectively) by means of a thermal-optical method (Pio et al., 1994). The remaining parts of the filters were extracted with dichloromethane (DCM) and ultra-pure water. The obtained 


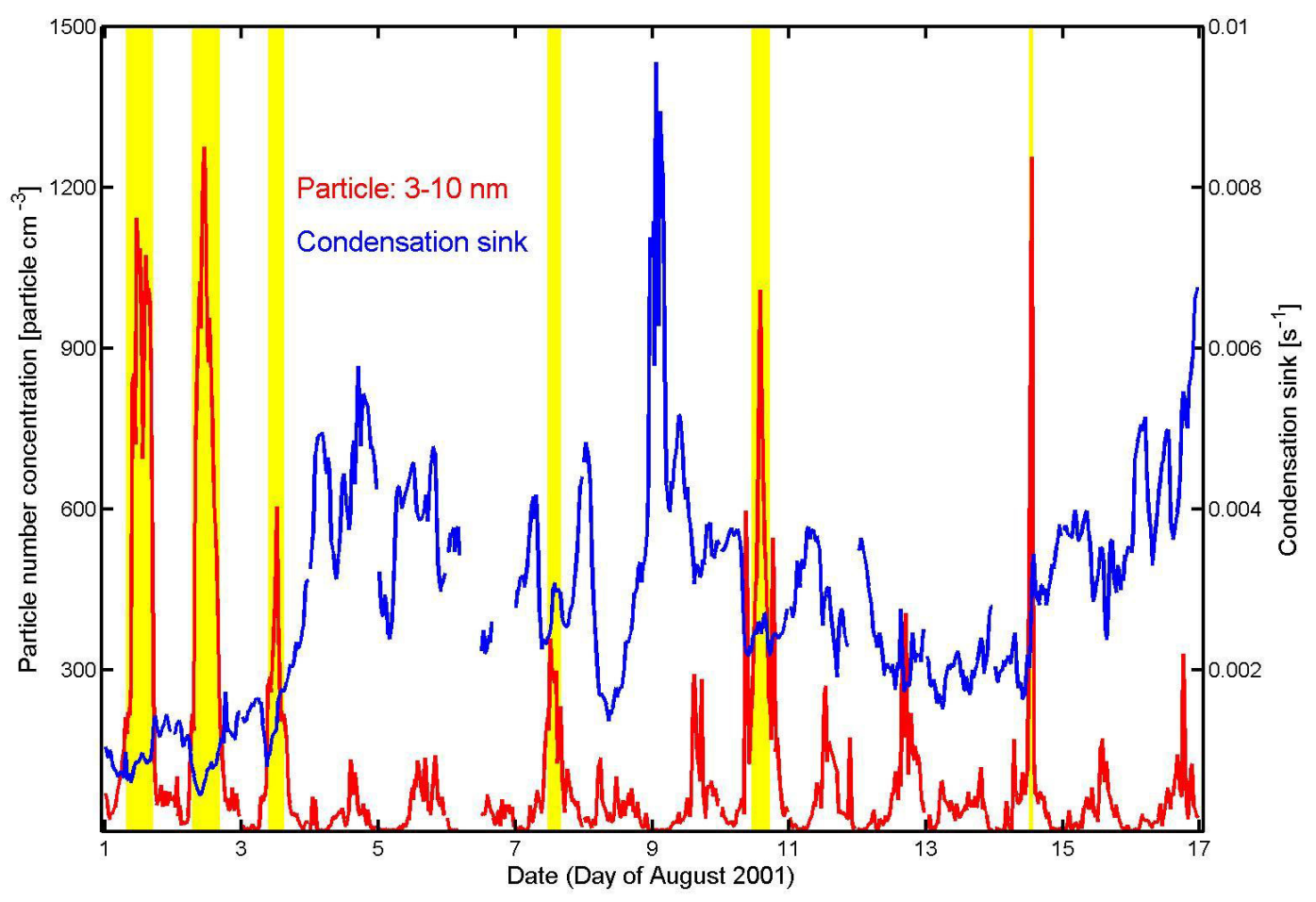

Fig. 2. Half hour average values for the number concentration of the nucleation mode particles (3-10 nm) and condensational sink. The yellow areas mark the periods when bursts of nucleation mode particles were observed.

extracts were analysed by a thermal-chemical method and GC-MS (Alves et al., 2001, 2002; Carvalho et al., 2003).

2.7 High-volume sampling of organic aerosols and analysis by LC-TOF-MS

$\mathrm{PM}_{2}$ aerosol samples were collected on preheated quartz filters using a Digitel high volume sampler at flow rates of $1 \mathrm{~m}^{3} \mathrm{~min}^{-1}$. Terpene oxidation products were measured with $12 \mathrm{~h}$ sampling time between 1 and 10 August. The filters were extracted with $10 \%$ methanol and were analyzed by LC-TOF-MS (Applied Biosystems, Langen, Germany) (Römpp and Moortgat, 2000).

$2.8 \mathrm{PM}_{2.5}$ sampling on quartz fibre filters and analysis by HPLC-ESI-MS-Analysis

For $\mathrm{PM}_{2.5}$ particle sampling quartz fibre filters with a diameter of $70 \mathrm{~mm}$ (mounted in stainless steel filter holders) were used. A sampling flow rate of $2.3 \mathrm{~m}^{3} \mathrm{~h}^{-1}$ was applied. During the Hyytiälä-campaign a backup filter was placed behind the front filter to determine possible sampling artifacts (see Kirchstetter et al., 2000, 2001). The duration of the sampling was about $12 \mathrm{~h}$, usually divided in day and night samples. Prior to extraction the filters were spiked with a standard (camphoric acid) for determination of the recovery rate. Afterwards the filters were extracted in an ultrasonic bath using methanol as solvent. The analysis was done by a capillary-HPLC-ESI-IT-MS system (ThermoFinnigan, San Jose, USA).

\section{Results and discussion}

The results of the experiments are divided into five sections. Section 3.1 contains the characteristics of the aerosols. In Sect. 3.2 precursor measurements of different gases are discussed and Sect. 3.3 presents the chemical characterisation of photo-oxidation products of VOCs in the gas- and particlephase. In Sect. 3.4 chemical aerosol analyses from different institutes are introduced and in Sect. 3.5 we give an overview of the meteorology including solar radiation during the time of the field campaign in Hyytiälä.

\subsection{Characterisation of the aerosols}

\subsubsection{Time of particle bursts and condensational sink}

Nucleation events or particle bursts measured at sizes $>3 \mathrm{~nm}$ with the DMPS system were observed on the first three days in August and in less clear patterns on 7, 10 and 14 August (Fig. 1). On all event days apart from 7 and 10 August we observed high number concentrations (6001300 particles $\mathrm{cm}^{-3}$ ) of small nucleation mode particles (3$10 \mathrm{~nm}$ ) followed by a continuous growth to the Aitken and sometimes even accumulation mode. 7 and 10 August are 
Table 2. Growth rates, estimated vapour concentrations, source rates and particle formation rates during observed particle formation bursts during OSOA field campaign.

\begin{tabular}{|c|c|c|c|c|}
\hline Day & Growth rate & Vapour conc. & Vapour source & $\begin{array}{c}\text { Formation rate } \\
\text { for } 3 \mathrm{~nm} \text { particles }\end{array}$ \\
\hline & $\mathrm{nm} \mathrm{h}^{-1}$ & 107 molecules $\mathrm{cm}^{-3}$ & 105 molecules $\mathrm{cm}^{-3} \mathrm{~s}^{-1}$ & particles $\mathrm{cm}^{-3} \mathrm{~s}^{-1}$ \\
\hline 1 Aug. & 6.24 & 8.79 & 1.08 & 0.24 \\
\hline 2 Aug. & 10.74 & 15.22 & 1.27 & 0.38 \\
\hline 3 Aug. & 10.41 & 14.74 & 2.64 & 0.17 \\
\hline 7 Aug. & 9.59 & 13.38 & 4.93 & 0.31 \\
\hline 10 Aug. & 9.37 & 13.13 & 4.73 & 0.18 \\
\hline 14 Aug. & 37.95 & 54.58 & 19.14 & 1.72 \\
\hline
\end{tabular}

objectively difficult to declare as an event or a non-event day, however, for a wider discussion field we consider both days as nucleation days in this publication. In the single subplots thin red lines mark the onset and the end of the particle bursts, based on limit of 200 particles $\mathrm{cm}^{-3}$ in the nucleation mode. When this limit was exceeded or the concentration fell below, a nucleation event was considered to be started or ended. This limit is set in order to obtain some time interval for the nucleation event. Difficulty in selecting a correct period is due to the fact that growth from cluster sizes $(1 \mathrm{~nm})$ to the detection limit of the instrument $(3 \mathrm{~nm})$ can vary under different atmospheric conditions.

Loss of condensable molecules to the pre-existing aerosol population can be described with the condensational sink (Kulmala et al., 2001b) as

$C S=\sum \beta_{i} \cdot r_{i} \cdot N_{i}$

where $r_{i}$ is the radius of the $\mathrm{i}$ :th size class, $N_{i}$ is the respective number concentration and $\beta_{i}$ the transitional correction factor, given by Fuchs and Sutugin (1970). In the calculations, values for the molecular mass and the diffusion volume of the condensing vapour were taken as the condensing species were sulphuric acid. Figure 2 gives 30-min average values of the number concentration of the nucleation mode particles, the calculated condensational sink and the nucleation event times for the whole campaign period. At all events we recognised a clear decrease of the condensational sink shortly before or at the start of the particle bursts. This phenomenon was observed for most of the events in Hyytiälä during the last years and could be explained by the onset of turbulence and the growth of the mixed layer, which mixes relatively clean air from the residual layer with more polluted air masses from the surface layer (Boy and Kulmala, 2002b; Nilsson et al., 2001b). Further the values of the condensational sink on the event days in the beginning $\left(\mathrm{CS} \cong 0.001 \mathrm{~s}^{-1}\right)$ were two to three times smaller than on the other event days $\left(\mathrm{CS} \cong 0.002-0.003 \mathrm{~s}^{-1}\right)$. 7 August with the lowest number concentration of nucleation mode particles also shows the highest condensational sink values. These results indicate that high number concentration of existing aerosols reduce or prevent the formation of new particles by acting as sinks for the condensing vapours or the very small newly-formed particles $\left(\mathrm{D}_{p}<3 \mathrm{~nm}\right)$.

\subsubsection{Growth rate of particles and calculated gas concen- trations}

The growth rates of the newly formed particles during the early stages (first few hours) of growth were obtained from the DMPS data, according to the change in the maximum diameter the new particles had reached by the end of formation. Assuming that the growth rate is constant during the formation period, condensation theory enables us to estimate the amount of condensable vapour present. For the condensable vapour we can write a simple differential equation

$\frac{d C}{d t}=Q-C S * Q$

where $Q$ is the vapour source rate and $C S$ the condensation sink caused by the existing aerosol. Assuming that the vapour concentration changes slowly, we can use a steadystate approximation and estimate the source rate by setting $d C / d t=0$. A detailed description of this method can be found from Dal Maso et al. (2002). The results of this analysis are given in Table 2 . The growth rates $\left(6-11 \mathrm{~nm} \mathrm{~h}^{-1}\right)$ and the calculated vapour concentrations $\left(8-1510^{7}\right.$ molecules $\left.\mathrm{cm}^{-3}\right)$ and sources (1-5 $10^{5}$ molecules $\left.\mathrm{cm}^{-3} \mathrm{~s}^{-1}\right)$ are rather high compared to long-term mean values observed in Hyytiälä, but are quite comparable with earlier summertime observations. However, 14 August with about by a factor of 4 higher values than the other event days seems to be questionable: event or advection of polluted air masses. We discuss this day in the following sections in more detail.

\subsubsection{Water and ethanol vapour uptake properties of aerosols}

The hygroscopic properties of the ambient aerosol during this campaign were found to be very similar to reported values by 


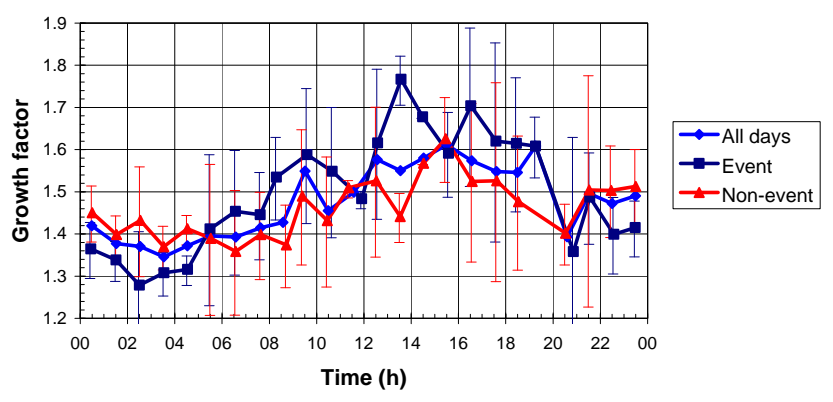

Fig. 3. Hourly averages of hygroscopic growth factors in water vapour of all days, nucleation event and non-event days (dry particle size $100 \mathrm{~nm}$ ).

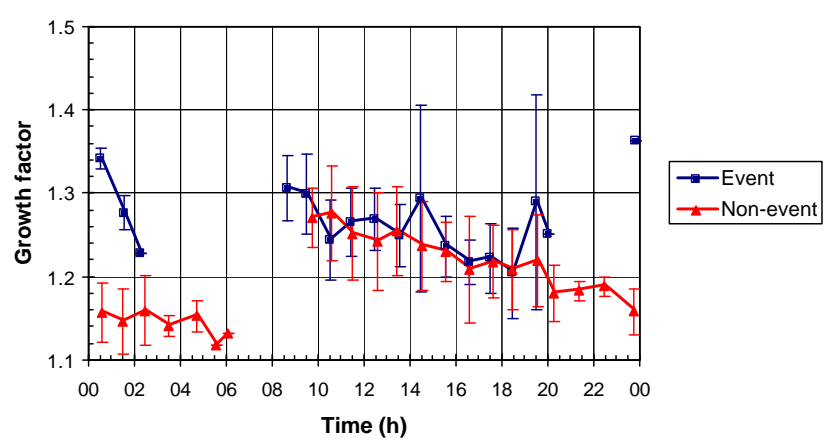

Fig. 4. Hourly averages of growth factors in ethanol vapour for nucleation event and non-event days (dry particle size $100 \mathrm{~nm}$ ).

Hämeri et al. (2001) in previous campaigns. On average, the ambient aerosol in Hyytiälä is quite inert in terms of water uptake, and it can mostly be classified to the less hygroscopic mode based on their growth factors $(\mathrm{GF}=1.1-1.4)$. According to laboratory measurements, oxidation products of $\alpha$ pinene (biogenic VOC, GF=1.1, Virkkula et al., 1999) and toluene (anthropogenic VOC, GF=1.2, Petäjä et al., 2002) belong to this group.

In order to study diurnal variations in water uptake, concentration weighed averages of measured hygroscopic growth factors in water were calculated. For internally mixed aerosol this is just the observed growth factor but in case of externally mixed aerosol, averaging ensures that the dominant hygroscopic fraction is weighed more and thus affects the average hygroscopic properties more. External mixing with respect to water uptake prevails for sizes larger than $50 \mathrm{~nm}$ in diameter. Growth factors in ethanol were more internally mixed and only one growth factor was observed most of the time. This indicates same ethanol uptake for all particles in the ambient aerosol population.

Distinct diurnal variation in the hygroscopic properties of aerosols is obvious in Hyytiälä. Considering hourly averages of all days of the campaign (Fig. 3), the growth factors are usually larger and more variable during daytime than during nighttime. Roughly between 8 a.m. and 8 p.m., growth

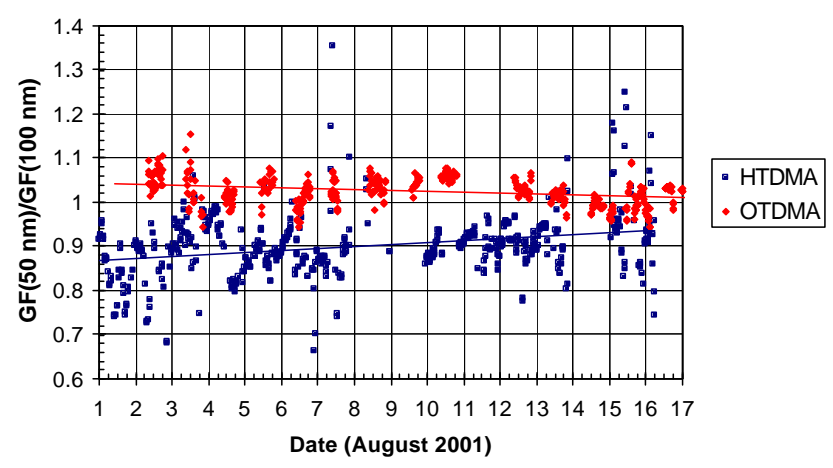

Fig. 5. Time series for the fraction of 50 to $100 \mathrm{~nm}$ particle growth factors $(\mathrm{GF}(50 \mathrm{~nm}) / \mathrm{GF}(100 \mathrm{~nm}))$ in water (HTDMA) and ethanol (OTDMA) vapours.

factors are larger than 1.4 for $100 \mathrm{~nm}$ particles. Maximum growth factors above 1.6 as hourly averages are observed during afternoon hours. During nighttime, growth factors are stable and between 1.3 and 1.4.

When nucleation days and the days with no nucleation burst are considered separately (Fig. 3), it can be noticed that the daily maximum is somewhat higher during nucleation days, whereas non-nucleation days exhibit more stable water uptake throughout the day and night. A slight decrease in water uptake prior to sunrise is present during all days, but hourly averaged growth factors are lower before nucleation bursts than during the days, when nucleation does not take place.

Figure 4 shows the average growth factors of $100 \mathrm{~nm}$ particles in ethanol vapour with saturation ratios of $0.90 \pm 0.02$ for event days and non-event days. A maximum value of around $1.3-1.35$ is reached in the morning, after which the GF gradually decreases to values closer to 1.2 by $8 \mathrm{p} . \mathrm{m}$. There are only three nighttime measurement series, showing a somewhat different behaviour. In one series after a nucleation event day (14 August 2001) the GF decreases rapidly from above 1.35 at midnight to 1.2 at $3.30 \mathrm{a} . \mathrm{m}$. and in the other series after non-event days the GF remains at a nearly constant value of 1.15 throughout the night. Figure 4 also reveals that, unlike the hygroscopicity, the daytime behaviour of ethanol GFs is very similar during nucleation event and non-event days.

Figure 5 shows two time series which compare the behaviour of $50 \mathrm{~nm}$ and $100 \mathrm{~nm}$ particles in both water and ethanol vapours. The hygroscopic growth factors of $50 \mathrm{~nm}$ particles are most of the time somewhat smaller than those of $100 \mathrm{~nm}$ particles with the average of the fraction $\mathrm{GF}(50 \mathrm{~nm}) / \mathrm{GF}(100 \mathrm{~nm})$ close to 0.9 . The difference is mostly too large to be explained (at least solely) by the Kelvin effect, indicating that the compositions of the $50 \mathrm{~nm}$ and $100 \mathrm{~nm}$ particles are usually somewhat different. A further proof of this is the similar time series for the fraction of 50 to $100 \mathrm{~nm}$ particle growth factors in ethanol 


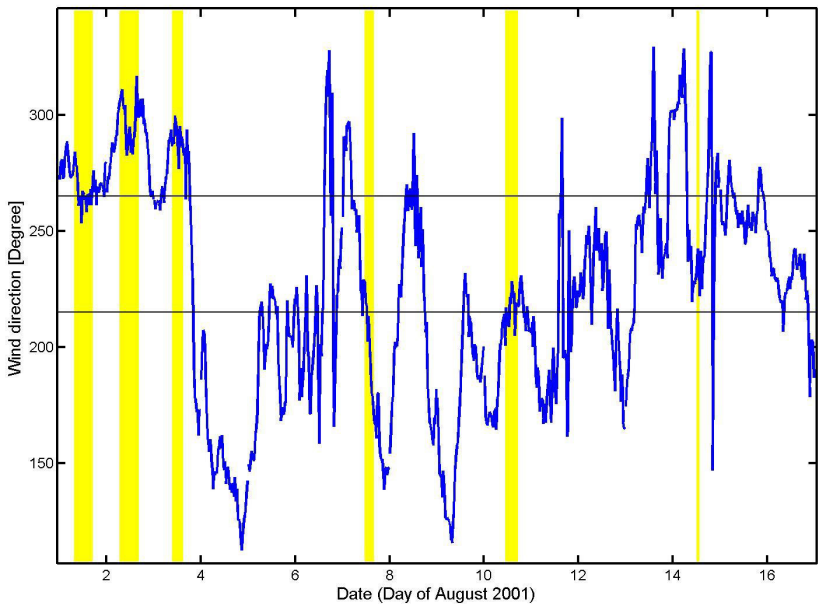

Fig. 6. Half hour average values of the wind direction. The yellow areas mark the periods when bursts of nucleation mode particles were observed and the thin black line is the wind-sector from Tampere and the station building.

vapour. It can be seen that the $50 \mathrm{~nm}$ particles grow more in ethanol than do $100 \mathrm{~nm}$ particles, with the average of $\mathrm{GF}(50 \mathrm{~nm}) / \mathrm{GF}(100 \mathrm{~nm})$ close to 1.02 . Note, that if the Kelvin effect could be accounted for, this number should be even slightly higher. A possible explanation for the data shown in Fig. 5 is that the $100 \mathrm{~nm}$ particles contain a somewhat higher fraction of inorganic salts and a somewhat lower fraction of organic materials than do the $50 \mathrm{~nm}$ particles. Furthermore, chemical composition of the organic matter can vary in different size ranges. For instance, organic compounds in larger particles $(100 \mathrm{~nm})$ can be more aged (longer residence time in the atmosphere) than smaller particles and thus they can be, e.g. higher oxidized and thus can be more water soluble and possibly also less ethanol soluble. However, this interpretation cannot be considered conclusive without a chemical analysis of the particles.

\subsubsection{Aerosol flux measurements}

The particle flux measurements were performed throughout the campaign. However, during most of the days unfavourable wind direction conditions for particle flux observation prevailed (see Fig. 6): under South-westerly wind $\left(215-265^{\circ}\right)$ the forestry field station buildings act as a source of aerosol particles and corresponding fluxes do not correspond to background conditions (Buzorius et al., 2001). Under such conditions the particles emitted from the station will be seen as upward fluxes accompanied with an erratic pattern in the flux time series, in contrast to normal background conditions when particle deposition into the forest occurs.

During the first three days in August when particle formation was observed the wind direction was different than the sector corresponding to field station. During these days particle number concentration decreased at night prior to par-
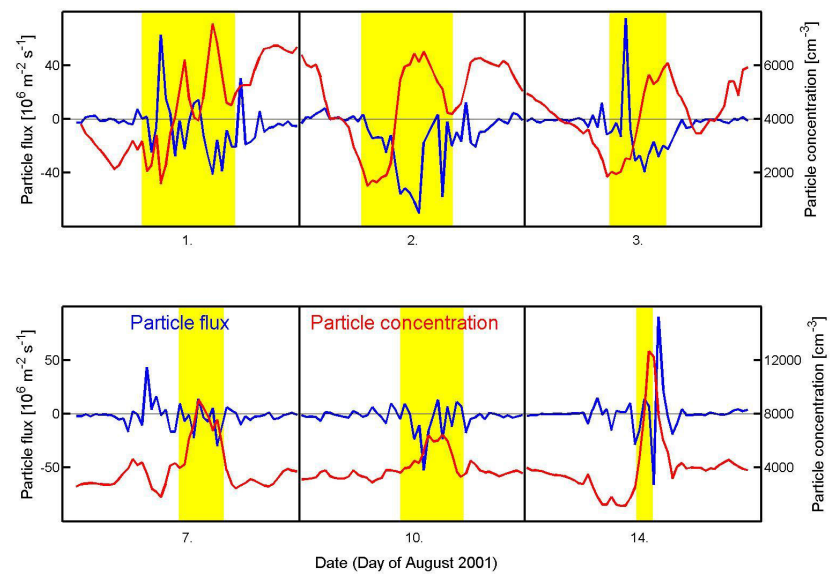

Fig. 7. Half hour average values for the particle number concentration measured by the CPC from the EC system at $23 \mathrm{~m}$ and calculated particle fluxes. The yellow areas mark the periods when bursts of nucleation mode particles were observed.

ticle formation (Fig. 7). The nights were moderately stable, but turbulent transport of heat and momentum (friction velocity around $0.2 \mathrm{~m} \mathrm{~s}^{-1}$ ) did not cease. However, particle fluxes were very small as typically observed at the measurement site (Buzorius et al., 2001). During the particle bursts periods a rapid increase in particle concentration together with very large downward fluxes was observed $\left(\mathrm{P}_{\text {Flux }}: 30\right.$ $7010^{6}$ particles $\mathrm{m}^{-2} \mathrm{~s}^{-1}$ ). The very high flux values during particle formation events result from elevated particle number concentration as well as domination of small nucleation mode particles in size spectrum, which have very high deposition velocities (e.g. Peters and Heiden, 1992). Similar behaviour but with more variation in fluxes can be seen on the other three event days. In addition to non-stationary, rapid changes in particle concentration, meteorological reasons such as horizontal advection and circulation in the convective mixed layer can cause significant variation in observed fluxes (Nilsson et al., 2001b).

The fluxes obtained from measurements present average fluxes of particles larger than $10 \mathrm{~nm}$ in diameter. During nucleation events these fluxes indicate mainly the vertical motion of small particles: deposition of these particles into the forest was observed. The result also implies the existence of a higher concentration of these particles up in the atmospheric boundary layer.

\subsubsection{Vertical aerosol profiles}

The optical particle counter (OPC) was operated on the balloon as described in Sect. 2 from 2 August through $12 \mathrm{Au}-$ gust, whereas the CPC instrument was flown only from 7 August (start 3 p.m.) till 12 August. As a consequence, CPC data cover exclusively days without obvious particle formation events. 


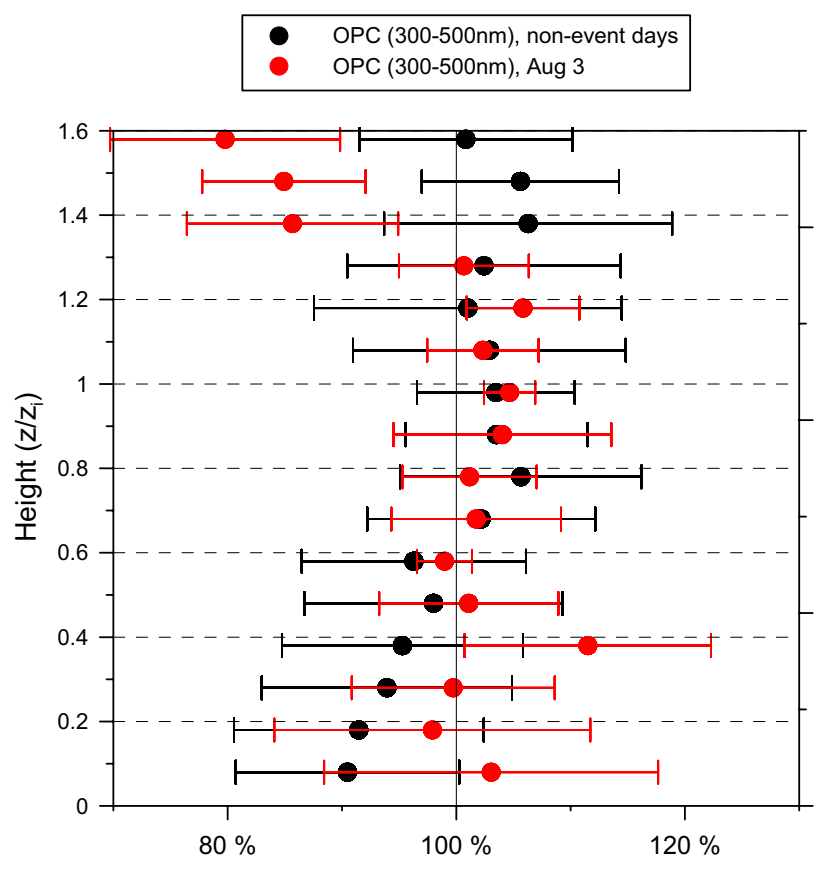

Fig. 8. Vertical profiles of particle number concentrations. Concentrations are normalized to the average in the mixed layer, altitude is given as height above ground divided by boundary layer depth $\left(\mathrm{z} / \mathrm{z}_{i}\right)$. Only profiles with measurements both in the mixed layer $\left(\mathrm{z} / \mathrm{z}_{i}<1\right)$ and above $\left(\mathrm{z} / \mathrm{z}_{i}>1\right)$ are included; error bars denote standard deviations of the sample (3 August, $n=6$, other days $n=33$ ).

Profiles obtained by this method represent instantaneous snapshots of the vertical particle distribution. This is documented by large variations in particle numbers at comparable heights between individual profiles. Variations from one profile flight to the next (time gap of at least $2 \mathrm{~h}$ ) or even between ascent and descent of the same flight $(30 \mathrm{~min})$ are large.

Some distinct features could be observed by looking at the vertical distribution of particles in a relative way, by looking at number concentrations normalized to the averaged concentration over the mixed layer. As can be seen in Fig. 8, there was a different vertical trend in particle concentrations $(>300 \mathrm{~nm}$ ) on 3 August as compared to the average profile recorded on non-event-days. On 3 August, particle concentrations above the planetary boundary layer (PBL) were small and no significant gradient within the PBL could be observed, whereas increasing aerosol concentrations with height were observed on the other days.

During three flights, the CPC and OPC were run in parallel. Of the resulting 10 profiles, some show different vertical trends for different particle sizes (Fig. 9). It indicates that particles of the sizes most interesting for nucleation events may have an opposite gradient than larger particles. Summarising both figures, no indication for preferred particle formation above the surface layer or in the free troposphere appears, the results indicate that the formation of new

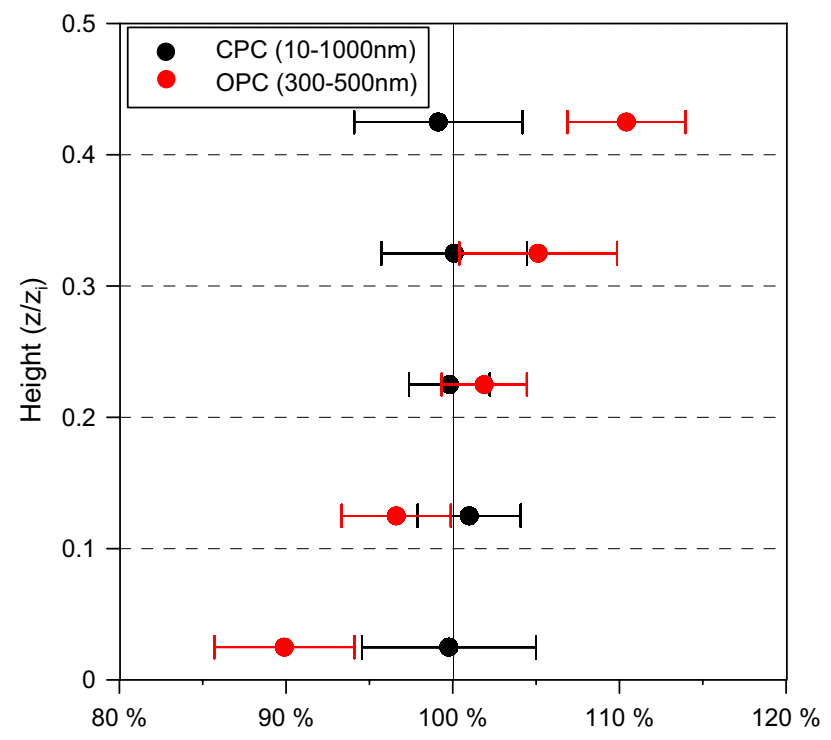

Fig. 9. Vertical particle concentration gradients for different sizes, plotted in the same way as in Fig. 8; average of 4 profiles measured on 8 August, 14:30-15:30.

particles happens throughout the boundary layer in a more or less homogenous pattern. In this context Stratmann et al. (2003) measured with two CPCs with different cut-offs (5 and $10 \mathrm{~nm}$ ) homogenous distribution of particles with $\mathrm{D}_{p}=5-$ $10 \mathrm{~nm}$ in the mixed boundary layer during an event day near Leipzig, Germany.

More information of this type (especially measurements of particles $<300 \mathrm{~nm}$ ) during nucleation events may provide valuable data for the interpretation of particle formation. As the results indicate, such efforts ideally would include not only measurements of particle numbers, but also information about the size distribution.

\subsection{Precursor measurements}

\subsubsection{Ozone, $\mathrm{SO}_{2}$ and $\mathrm{NO}_{\mathrm{x}}$}

The concentrations of different gases $\left(\mathrm{O}_{3}, \mathrm{NO}_{\mathrm{x}}\right.$ and $\left.\mathrm{SO}_{2}\right)$ monitored continuously in Hyytiälä SMEAR II were analysed for the time of the OSOA field campaign (at $16 \mathrm{~m}$ level) and plotted as half-hour average values in Fig. 10. During the experiment the ozone concentrations were varying between 10 and $40 \mathrm{ppb}$ with a clear diurnal profile. However, there were no visible trends of higher or lower values at times of new particle formation, neither in the daily maxima nor in the gradients prior to the particle bursts $\left(\mathrm{d}\left[\mathrm{O}_{3}\right] / d t\right)$.

$\mathrm{NO}_{\mathrm{x}}$ and $\mathrm{SO}_{2}$ mixing ratios were varying during the campaign between 0.068 to $2.98 \mathrm{ppb}$ and below detection limit to $1.34 \mathrm{ppb}$, respectively. If we compare the mixing ratios of $\mathrm{NO}_{\mathrm{x}}$ with the wind direction from Fig. 6, we recognise higher values during the times, when probably more polluted air masses from Southwest (also with high values for aerosol 


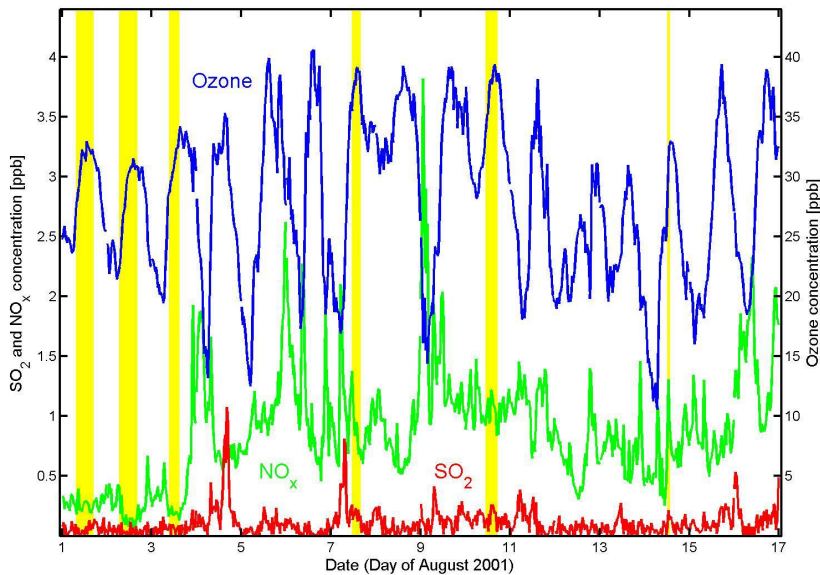

Fig. 10. Half hour average values of $\mathrm{O}_{3}, \mathrm{NO}_{\mathrm{x}}$ and $\mathrm{SO}_{2}$. The yellow area marks the periods when bursts of nucleation mode particles were observed.

condensational sink - see Fig. 2) arrived at the station. So the first three clear event days in the beginning of August show the lowest concentrations of $\mathrm{NO}_{\mathrm{x}}$ and also $\mathrm{SO}_{2}$. The other events later on are more polluted with 2 to 4 times higher values for both gases. Although $\mathrm{SO}_{2}$ (or the oxidised form $\mathrm{H}_{2} \mathrm{SO}_{4}$ ) is involved through binary or ternary nucleation in the formation of TSCs, in the real atmosphere the influence of other parameters such as the condensational sink may be also important for the formation of new aerosols.

\subsubsection{VOC measurements on tethered balloons}

During the OSOA field campaign a total of 80 VOC samples were collected onto cartridges from balloon platforms. In addition, VOC probes were taken on the SMEAR II mast at heights between 23 and $43 \mathrm{~m}$ above ground. The goal of these measurements was to determine fluxes of biogenic VOC, terpenes in particular, at both local and regional scales.

The analyses of the balloon samples focused on monoterpenes and isoprene. Terpene mixing ratios in the PBL during that period were in the order of a few ppt, with $\alpha$ pinene, limonene, $\Delta_{3}$-carene and camphene as the major compounds. Isoprene was also found in most samples, although at lower mixing ratios than monoterpenes. In comparison to earlier measurements at Hyytiälä, the contribution of $\alpha$-pinene to the sum of terpenes was smaller in these PBLmeasurements (Fig. 11a). Averaged VOC profiles (especially monoterpenes) within the PBL showed a decreasing trend with height, as would be expected for gases with a source at the surface (Fig. 11b).

Daily averages of all VOC samples taken within the PBL are shown in Fig. 12. Days with particle formation events (2, 3 and 7 August) had low terpene mixing ratios. Note however, that a direct comparison of days is difficult, as the temporal coverage with balloon soundings varies significantly from day to day.
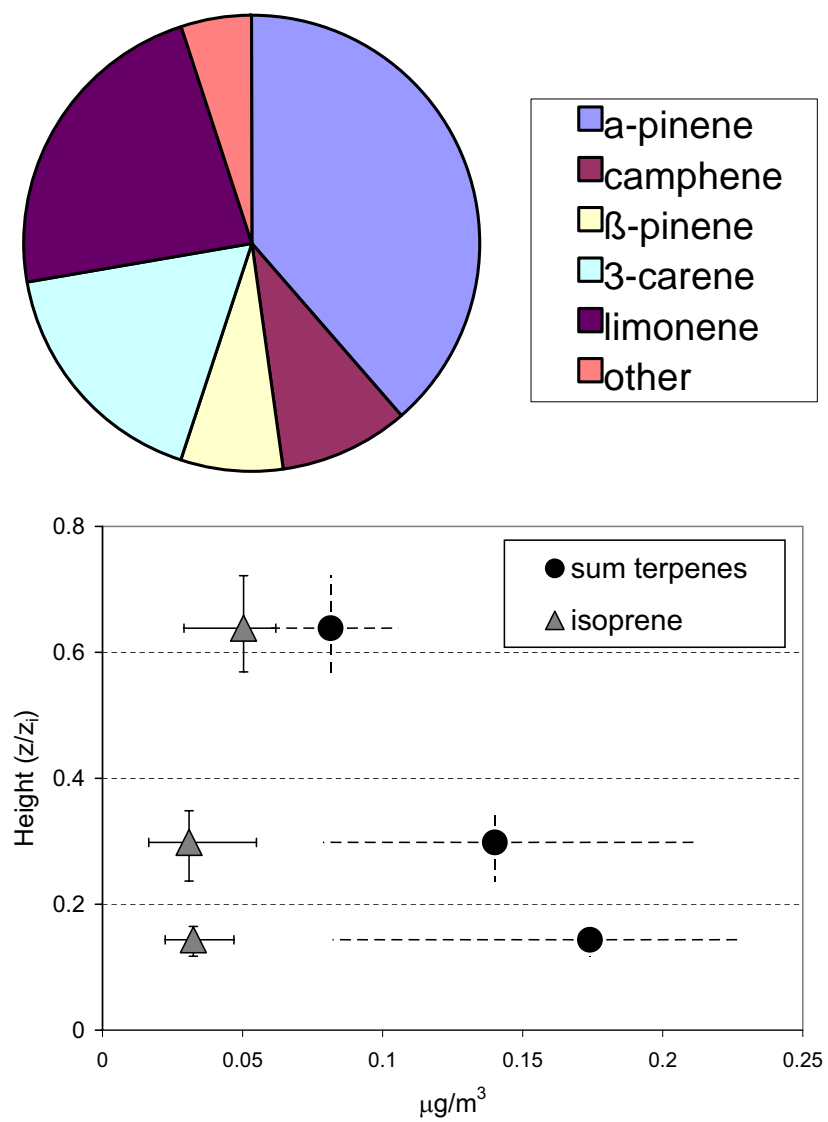

Fig. 11. Averaged monoterpene concentrations from balloon samples, (a) mean composition, (b) profile of medians (error bars are interquartile ranges).

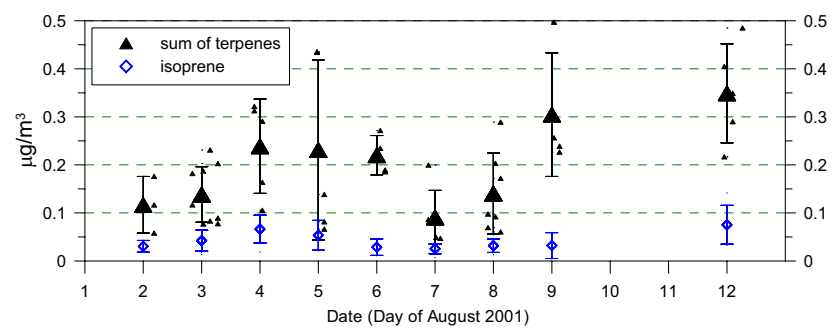

Fig. 12. Biogenic VOC concentrations during the OSOA campaign 2001. Large symbols are daily averages (error bars are standard deviations) of all measurements taken within the PBL (small symbols).

The VOC measurements from balloons were used to derive fluxes of biogenic VOC. The footprints of fluxes obtained from measurements in the PBL are of the order from tens to hundreds of square kilometers, depending on the method applied. Uncertainties of fluxes determined in this way are largely due to the various assumptions included (Guenther et al., 1996). For example, homogenous emissions are assumed within the footprint area, a condition that is most 
Table 3. Organic compounds measured in the gas-phase.

\begin{tabular}{llcc}
\hline Compound name & Formula & \multicolumn{2}{c}{ Concentration Range } \\
\hline & & $\mu \mathrm{g} \mathrm{m}^{-3}$ & molecules cm \\
\hline Aldehydes and Ketones & & & \\
Formaldehyde & $\mathrm{HCHO}$ & $0.18-0.98$ & $3.610^{9}-2.010^{10}$ \\
Acetaldehyde & $\mathrm{CH}_{3} \mathrm{CHO}$ & $0.12-3.24$ & $1.710^{9}-4.710^{10}$ \\
Acetone & $\mathrm{CH}_{3} \mathrm{COCH}_{3}$ & $0.24-1.8$ & $2.510^{9}-1.910^{10}$ \\
Acrolein & $\mathrm{H}_{2} \mathrm{CHCHO}_{3}$ & $<0.01-1.33$ & $<1.110^{8}-1.410^{10}$ \\
Propionaldehyde & $\mathrm{CH}_{3} \mathrm{CH}_{2} \mathrm{CHO}$ & $0.02-0.38$ & $2.110^{8}-4.010^{9}$ \\
Hexanaldehyde & $\mathrm{CH}_{3}\left(\mathrm{CH}_{2}\right)_{4} \mathrm{CHO}$ & $<0.01-0.31$ & $<6.010^{7} 1.910^{9}$ \\
\hline
\end{tabular}

commonly violated in practice. Landscape fluxes therefore need to be determined from averaged VOC profiles reflecting various conditions and wind directions. As a consequence, the advantage of deriving a flux representative for the scale of a whole landscape is accompanied by limited temporal information about the flux.

The mean terpene fluxes as derived from balloon measurements between 2 August and 12 August were between 140 and $300 \mu \mathrm{gC} \mathrm{m}^{-2} \mathrm{~h}^{-1}$, depending on the method applied. Assuming the discrepancy is mainly a consequence of the different footprints of the methods, we conclude that terpene emissions averaged over a region of several hundreds of $\mathrm{km}^{2}$ surrounding Hyytiälä are less than those of the region covering tens of $\mathrm{km}^{2}$ close to the site. The same trend of lower emissions with increasing footprint area exists in the comparison of balloon results with measurements from the mast. The average of the terpene fluxes determined from gradients on the mast on 15 August was $330 \mu \mathrm{gC} \mathrm{m}^{-2} \mathrm{~h}^{-1}$. This corresponds to a basal emission rate $\left(30^{\circ} \mathrm{C}\right)$ of $900 \mu \mathrm{gC} \mathrm{m}^{-2} \mathrm{~h}^{-1}$; a value similar to earlier flux measurements on the tower (Rinne et al., 2000).

3.3 Chemical characterisation of photo-oxidation products of VOCs in the gas- and particle-phase.

Chemical analyses of the gas-phase and particle-phase were performed in order to study the spatial distribution of measured species.

\subsubsection{Carboxylic acids and carbonyls}

The concentrations of gas-phase carboxylic acids and carbonyls observed during the campaigns were measured by two independent groups (Environmental Chemical Processes Laboratory- ECPL, and University of Aveiro - UVAR). The results are shown in Fig. 13 and Table 3. The data reported by ECPL, concerning the gaseous concentration of small carboxylic acids support the hypothesis that biogenic emissions are sources of atmospheric formic and acetic acid. The concentration of formic acid ranged from 0.52 up to $5.04 \mu \mathrm{g} \mathrm{m}^{-3}$
(6.8-66 $10^{9}$ molecules $\mathrm{cm}^{-3}$ ) while the corresponding concentration for acetic acid ranged from 0.41 up to $4.06 \mu \mathrm{g} \mathrm{m}^{-3}$ (4.1-41 $10^{9}$ molecules $\mathrm{cm}^{-3}$ ). The general trends in both formic and acetic were similar showing a high degree of correlation (Fig. 13a) suggesting that their sources should be closely related. The formate to acetate ratio varied from 1.04 to 1.43 (mean value of 1.26), indicating thus predominance of formic acid in the forested area of Hyytiälä. This comes in accordance with the observations by Chebbi et al. (1996) that formic acid is the main product of isoprene and monoterpenes (emitted by trees) oxidation by ozone. The same trend has been observed in a previous study in a Eucalyptus forest in Portugal (Kavouras et al., 1998). Photochemical production (that favours formic acid) seems to play a more important role than direct emissions from vegetation (that favours acetic acid). Acetic acid concentrations can be increased by anthropogenic emissions (Kawamura et al., 1985) and/or biomass burning (Talbot et al., 1987). This seems not to happen in the investigated area. Measurements of the same acids conducted by UVAR resulted to the same mean formate to acetate ratio value of 1.26. Both laboratories observed a predominance of maxima during daytime and minima during nighttime (Fig. 13a).

Formaldehyde presented a smooth diurnal variation with maxima during daytime and minima during nighttime. Acetaldehyde and acetone exhibited also a predominance of daytime maxima. Nevertheless these carbonyl compounds presented the highest concentrations during nighttime. Acrolein exhibited a strong diurnal variation of concentrations with maxima during nighttime and minima during daytime. The most pronounced variation occurred between 7 and 11 August. Propionaldehyde didn't present a characteristic diurnal variation and the highest concentrations of hexanaldehyde were observed mainly at night.

\subsubsection{Gas/particle partitioning of photo-oxidation products}

The volatile and semi-volatile of the polar and acidic fractions in both particulate and gas phase were analysed. A series of monoterpene-skeletoned photo-oxidation carbonyl 

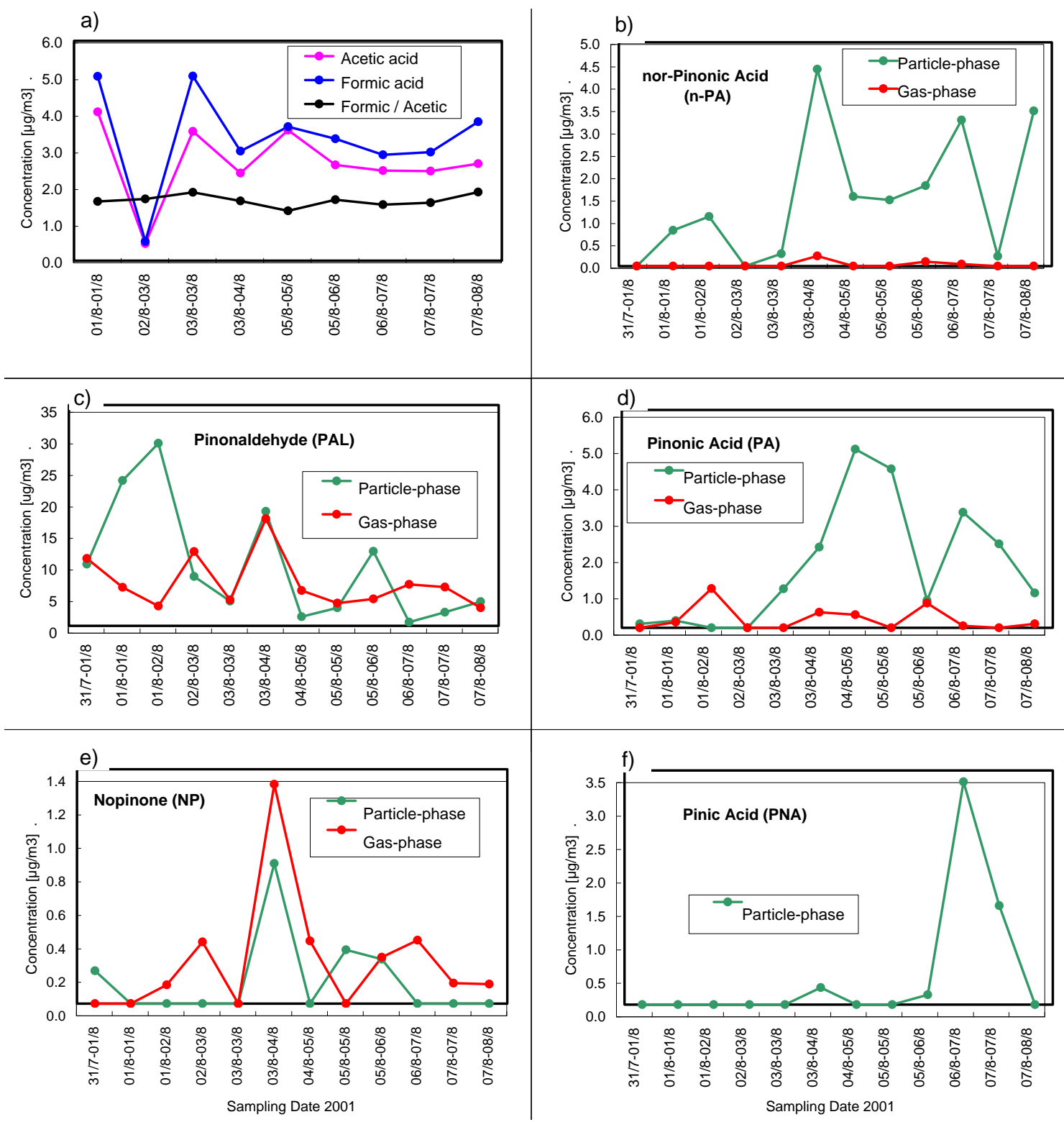

Fig. 13. Gas- and particle-phase concentrations of some photo-oxidation products for the first eight days in August 2001 with a sampling time of $12 \mathrm{~h}$ and start times at 6 p.m. and 6 a.m., respectively.

and acidic compounds were detected and quantified in both gas and particles over the Hyytiälä forest. In particular, 6,6-dimethyl- bicyclo[3.1.1]heptan-2-one (reported as nopinone) and 2,2-dimethyl-3-acetyl-cyclobutyl-ethanal (reported as pinonaldehyde), 2,2-dimethyl-3-acetyl-cyclobutylformic acid (reported as nor-pinonic acid), 2,2-dimethyl-3acetyl-cyclobutyl-acetic acid (reported as pinonic acid), and cis-2,2-dimethyl-3-carboxy-cyclobutyl-acetic acid (reported as pinic acid) were identified on the basis of their CI and EI mass spectra and comparison with authentic standards (Fig. 13b-f). These compounds have been determined as characteristic products of the photo-oxidation of $\alpha$ - and $\beta$ - pinene with ozone, $\mathrm{OH}$ and $\mathrm{NO}_{3}$ radicals, in laboratory studies. Pinonaldehyde and nopinone have shown for most of the sampling days higher gas- than particle-phase concentrations. Nighttime reactions of pinenes with $\mathrm{NO}_{3}$ radicals eventually contributed to the relatively elevated concentration of pinonaldehyde in the particulate phase. For pinonic, nor pinonic and pinic acids, concentrations in the particlephase were higher than the corresponding concentrations in the gas phase. Pinonic acid is produced through the reaction of $\alpha$-pinene with both $\mathrm{OH}$ radicals and ozone, and pinic acid is mainly formed through the reaction of $\alpha$ - and $\beta$-pinene with ozone. The concentration levels of pinonic acid and 
Table 4. The total concentration ranges and carbon preference indexes for some of the detected homologue compounds series.

\begin{tabular}{lccccc}
\hline $\begin{array}{l}\text { Compounds } \\
\text { Class }\end{array}$ & $\begin{array}{c}\text { Concentration } \\
\text { Range } \\
\left(\mathrm{ng} \mathrm{m}^{-3}\right)\end{array}$ & $\mathrm{C}_{\max }$ & $\begin{array}{c}\text { CPI } \\
\text { Whole range } \\
(\text { Petroleum) }\end{array}$ & $\begin{array}{c}\text { CPI } \\
\text { Split range } \\
(\text { Bacterial) }\end{array}$ & $\begin{array}{c}\text { CPI } \\
\text { Split range } \\
\text { (Plant wax) }\end{array}$ \\
\hline n-Alkanes & $7.2-95.2$ & $\mathrm{C} 27$ & $2.69 \pm 1.05$ & $1.83 \pm 0.69$ & $5.85 \pm 2.54$ \\
n-Alkanols & $1.0-17.4$ & $\mathrm{C} 26$ & $8.52 \pm 4.16$ & $3.33 \pm 1.82$ & $18.98 \pm 8.44$ \\
n-Monocarboxylic Acids & $39.0-192.0$ & $\mathrm{C} 16$ & $6.86 \pm 1.67$ & $7.00 \pm 2.18$ & $4.72 \pm 1.10$ \\
\hline
\end{tabular}

$\mathrm{C}_{\max }$ - Carbon number with the highest peak in the chromatogram;

CPI - Sum of the odd carbon number homologues divided by the sum of the even carbon number homologues over the range indicated for n-alkanes and the inverse for n-alkanols and n-alkanoic acids (Abas and Simoneit, 1996).

pinic acid show that the first is produced faster and in higher amounts than the second under real conditions. Thus, it is clear that the atmospheric concentrations of $\mathrm{OH}$ radicals and ozone have an effect on the composition of organic aerosol produced through the atmospheric photo-oxidation reactions. The data show the preference of the above discussed carboxylic acids to the particle phase and eventually their ability to condense under certain atmospheric conditions.

3.4 Chemical characterisation of organic compounds and photo-oxidation products of VOCs in Hyytiälä fine aerosols

Chemical analyses of coarse mode particles $\left(\mathrm{PM}_{2-10}\right)$ were performed by three groups with different sampling and analytical techniques, which gave the chance to compare the results of some measured species.

\subsubsection{Organic aerosols $\mathrm{PM}_{10}$ analysis}

Carbonaceous aerosol was one important component of the aerosol at the studied location. Organic carbon accounted for $27 \%$ of the $\mathrm{PM}_{10}$ mass concentration in Hyytiälä. Adding the contribution of black carbon, the share of total carbon reaches $34 \%$. Using the dichloromethane-extraction procedure $31 \%$ of the organic carbon could be extracted. The addition of the water-extract increased this ratio to $52 \%$, which is comparable to the $48 \%$ obtained during the short-term experiment (Alves et al., 2002).

On average the fraction of secondary carbon in the Finnish aerosol accounted for $71 \%$ of the organic carbon, which corresponds to $19 \%$ of the $\mathrm{PM}_{10}$ mass concentration. Secondary organic carbon was calculated by subtracting primary organic carbon from total organic carbon, assuming that the ratio between primary organic carbon and black carbon is 1.1 (Castro et al., 1999). In some periods the fraction of secondary organic carbon showed clear maxima during daytime and minima during nighttime. This is an obvious indication of local or regional formation of secondary aerosol, because even the interference of wood burning emissions, which is higher at night, did not cause the rise of the values calculated for night periods.

The total concentration ranges and carbon preference indexes (CPI) for n-alkanes, n-alkanols and n-mono-carboxylic acids are presented in Table 4. CPI is a diagnostic parameter, where a value higher than 3 indicates the major incorporation of recent biological constituents into the aerosol sample. The input of anthropogenic contaminants reduces the CPI, such that values of approximately 1 reflect the significant introduction of contaminants with human origin. $\mathrm{C}_{\max }$ (carbon number with the highest peak in the chromatogram) can also give an indication of relative source input and serves as a regional parameter of vascular plant contributions to the atmosphere (Abas and Simoneit, 1996). The distribution of the $\mathrm{n}$ alkanes ranged from $\mathrm{C}_{16}$ to $\mathrm{C}_{34}$, with $\mathrm{C}_{\max }$ equal to 27 . Odd carbon number predominance was found, especially in the range $\mathrm{C}_{n}>23$, wherein odd carbon number alkanes represent a primary major contribution of vascular plants waxes (Abas and Simoneit, 1996). The isoprenoid hydrocarbons derived from petroleum (pristane and phytane) were also detected.

The most representative PAHs in the sampling site were indeno[1,2,3-cd]pyrene, benzo[b+k]fluoranthene, benzo[a]anthracene, benzo[e]pyrene and benzo[a]pyrene. On average, the total concentration of PAHs in the Finnish samples $\left(8.9 \mathrm{ng} \mathrm{m}^{-3}\right)$ was lower than those from the previous short-term experiment in Finland $\left(17 \mathrm{ng} \mathrm{m}^{-3}\right.$, Alves et al., 2002).

Carbonyl compounds including linear homologues were detected. However, the discontinuity of the series makes the application of the CPI parameter for linear compounds impracticable. Table 5 presents the biogenically derived compounds detected in the samples, which includes some carbonyl compounds. Pinonaldehyde, 6,10,14-trimethyl2-pentadecanone and abieta-8,11,13-trien-7-one presented the highest concentrations in Hyytiälä. During the previous short-term experiment in Hyytiälä, pinonaldehyde was more abundant $\left(6.6 \mathrm{ng} \mathrm{m}^{-3}\right.$; Alves et al., 2002) and 
Table 5. Some primary and secondary compounds derived from biogenic sources.

\begin{tabular}{lcl}
\hline Compound name & $\begin{array}{c}\text { Max. conc. } \\
\left(\mathrm{ng} \mathrm{m}^{-3}\right)\end{array}$ & Proposed sources and References \\
\hline 6,10,14-trimethyl-2-Pentadecanone & 15.0 & $\begin{array}{l}\text { Degradation product of phytol found in plant wax (Simoneit et al., 1988) } \\
\text { Angiosperm wood burning or plant wax weathering }\end{array}$ \\
Triterpenones $\mathrm{C}_{30} \mathrm{H}_{48} \mathrm{O}$ (isomers) & 2.7 & (Standley and Simoneit, 1987; Simoneit, 2002) \\
\hline Cholesterol & 1.4 & Wood burning or plant wax weathering (Simoneit, 1989, 2002); \\
Stigmasterol & 2.4 & Cholesterol from meat cooking (Rogge et al., 1991) \\
$\beta$-Sitosterol & 25.0 & \\
\hline Pina ketone (Nopinone) & 0.2 & Photo-oxidation of alpha- and/or beta-Pinene (Yokouchi and Ambe, 1985; \\
Pinonaldehyde & 5.5 & Hoffmann et al., 1997; Christoffersen et al., 1998; \\
Pinonic acid & 2.6 & Winterhalter et al., 1999; Koch et al., 2000) \\
Pinic acid & 5.0 & \\
\hline Dehydroabietinal & 0.2 & \\
Abieta-8,11,13-trien-7-one & 2.1 & Degradation of resinous components by coniferous wood burning \\
6-Dehydrodehydroabietic acid & 0.5 & or natural weathering (Standley and Simoneit, 1987, 1994; \\
Dehydroabietic acid & 2.3 & Simoneit 1989, 2002) \\
7-Oxodehydroabietic acid & 0.1 & \\
\hline
\end{tabular}

trimethylpentadecanone was not a ubiquitous component of the aerosol. Nopinone and monoaromatic carbonyls, including benzaldehyde, were detected in all the experiments.

The homologous compound series of n-alkanols ranges from $\mathrm{C}_{11}$ to $\mathrm{C}_{30}$ in the Finnish site. The most abundant homologue was $\mathrm{C}_{26}$ and strong primary contributions of vascular plants waxes were found. Sterols were also present in the samples (Table 5).

The n-alkanoic acids are one of the dominant components in the extractable lipids. The homologous compound series ranges from $\mathrm{C}_{8}$ to $\mathrm{C}_{32}$ with an even carbon number predominance. The samples present a predominance of $\mathrm{C}_{\max }$ at $\mathrm{n}$ $\mathrm{C}_{16}$ that may reflect an enhanced primary microbial component and a less pronounced variable maxima for carbon number higher than 22. Alkanedioic acids were present in the aerosol samples from the Hyytiälä forest in a discontinuous series ranging from hexanedioic acid to docosanedioic. Nonanedioic was the most abundant constituent of this class and it has been suggested to be formed by photo-oxidation of oleic and linoleic acids (Yokouchi and Ambe, 1986; Kawamura and Gagosian, 1987; Stephanou and Stratigakis, 1993), which were also detected in the samples. Acids resulting from the photo-oxidation of pinene were also present in the aerosol phase (Table 6). Resin acids were also detected.

The compounds detected in the water-extract were polyhydroxy-, mono- and dicarboxylic acids, polyhydric alcohols (polyols) and sugars. The most representative individual compounds were malic acid, mannitol, arabitol, glucose and sucrose. Levoglucosan (1,6-anhydro- 3 -
D-glucopyranose) was also detected in the water-extract, though it is extracted predominantly by dichloromethane in the first extraction stage. This anhydrosugar is considered a specific tracer of biomass burning, which results from the depolymerization of cellulose at temperatures above $300^{\circ} \mathrm{C}$ (Simoneit et al., 1999). Table 6 also shows the concentration ranges for some water-extractable organic compounds. A more detailed discussion on the sources and size distributions of water-extractable organic compounds can be found elsewhere (Carvalho et al., 2003).

\subsubsection{Determination of VOC photo-oxidation products in $\mathrm{PM}_{2}$ and $\mathrm{PM}_{2.5}$}

The analysis of $\mathrm{PM}_{2}$ and $\mathrm{PM}_{2.5}$ measured in aerosol samples from Hyytiälä were performed by two independent groups. Group one (Institut für Specktrochemie, Germany) detected and quantified a series of organic acids, which originated from terpene ( $\alpha$-pinene) oxidation. The results are shown in Fig. 14. These acids, verified by commercially available standards, were norpinic, pinic and pinonic acid. Since their volatile precursors are of biogenic origin these less volatile substances can be used as marker compounds for the natural fraction of the tropospheric secondary organic aerosol. The concentrations of these compounds were mostly between 0.2 and $8 \mathrm{ng} \mathrm{m}^{-3}$ (for pinonic acid: $\approx 6.6$ $10^{5}$ and $2.610^{7}$ molecules $\mathrm{cm}^{-3}$ ). The $\mathrm{C}_{10}$-ketocarboxylic acid - pinonic acid - shows most times higher concentrations than the $\mathrm{C}_{9}$-dicarboxylic acid - pinic acid. Norpinic acid - 
Table 6. Some organic compounds detected in the water-extract.

\begin{tabular}{lcc}
\hline Compound name & Formula & Concentration Range $\left(\mathrm{ng} \mathrm{m}^{-3}\right)$ \\
\hline Malic acid (Hydroxibutanedioic) & $\mathrm{C}_{4} \mathrm{H}_{6} \mathrm{O}_{5}$ & $0.1-8.0$ \\
2-Hydroxiglutaric acid & $\mathrm{C}_{5} \mathrm{H}_{8} \mathrm{O}_{5}$ & $0.1-2.6$ \\
Arabitol & $\mathrm{C}_{5} \mathrm{H}_{12} \mathrm{O}_{5}$ & $1.4-241$ \\
Mannitol & $\mathrm{C}_{6} \mathrm{H}_{14} \mathrm{O}_{6}$ & $<0,5-88$ \\
Glucose & $\mathrm{C}_{6} \mathrm{H}_{12} \mathrm{O}_{6}$ & $1.3-41$ \\
Sucrose & $\mathrm{C}_{12} \mathrm{H}_{22} \mathrm{O}_{11}$ & $0.3-10$ \\
\hline
\end{tabular}

Table 7. Aerosol concentrations of terpene oxidation products.

\begin{tabular}{lccccc}
\hline & Number of samples & Minima & Maxima & \multicolumn{2}{c}{ Average } \\
\hline & & $\mathrm{ng} \mathrm{m}^{-3}$ & $\mathrm{ng} \mathrm{m}^{-3}$ & $\mathrm{ng} \mathrm{m}^{-3}$ & molecules cm $^{-3}$ \\
\hline Pinic acid & 16 & 2.0 & 21 & 5.6 & $1.810^{7}$ \\
Pinonic acid & 16 & 5.2 & 14 & 8.1 & $2.710^{7}$ \\
Norpinic acid & 16 & $\mathrm{n} . \mathrm{q}$. & 1.0 & 0.3 & $1.110^{6}$ \\
Sabinic acid & 16 & 0.7 & 4.1 & 1.9 & $5.010^{6}$ \\
Limonic and caric acid & 16 & 1.7 & 62 & 10 & $1.310^{7}$ \\
\hline
\end{tabular}

n.q.: below limit of quantification

a $\mathrm{C}_{8}$-dicarboxylic acid - is found at the lowest concentration levels, often below the detection limit.

The results from group two (Max-Planck-Institut für Chemie, Germany) are summarized in Table 7. Their measured average concentrations of pinic, pinonic and norpinonic acid were almost identical to the values from group one $\left(0.3\right.$ to $\left.8.1 \mathrm{ng} \mathrm{m}^{-3}\right)$. Furthermore, sabinic, caric and limonic acid were measured for the first time in ambient aerosol samples with average concentrations of 1.9 and $10 \mathrm{ng} \mathrm{m}^{-3}$, respectively. They were identified by comparison with laboratory experiments. Sabinene, limonene and carene were reacted with ozone in a smog chamber and the particles were collected. Sabinic acid could be quantified in the Hyytiälä samples. However, caric and limonic acid coeluted in the HPLC, so the concentrations stated are the sum of both acids. Sabinic, limonic and caric acid were quantified using pinic acid as a standard. Their concentrations exceeded the concentrations of pinic, pinonic and norpinic acid on several days. This shows that they have to be taken into account when assessing the contribution of terpene oxidation to secondary organic aerosol production.

Correlation analysis was done to get an indication of the source, biogenic or anthropogenic, of known and unknown compounds. The source can mean a source of primary emissions, a source of the precursor substances and/or the mechanism of formation (e.g. oxidation by ozone). As an example, one correlation analysis is shown for pinic and pinonic acid in Fig. 15. As can be expected the concentration of pinic and pinonic acid shows a good correlation, since both compounds are formed from the same precursor compound and both originate from identical degradation mechanisms. Furthermore, it can be seen that the average concentration of pinonic acid is almost twice that of pinic acid.

Within the samples from Hyytiälä a signal was observed which indicated the presence of a molecule with a molecular mass of $232 \mathrm{~g} \mathrm{~mol}^{-1}$. This compound was also observed in chromatograms from oxidation experiments of $\alpha$-pinene with $\mathrm{NO}_{\mathrm{x}}$ done in the CEAM-laboratory in Valencia as well as in samples from other laboratory experiments. Warscheid and Hoffmann (2002) suggested a structure based on online $\mathrm{MS}^{n}$ experiments made during ozone oxidation experiments in a smog chamber, as shown in Fig. 16. The molecule contains a carboxyl and a per-ester function and consequently can be supposed to have a very low saturation vapour pressure.

\subsection{Meteorology and solar radiation}

The last point from the results presented in this publication gives an overview of the meteorological situation during the campaign including the solar radiation. Figure 17 shows for all events half-hour average values of relative humidity, short wavelength irradiance $(300-340 \mathrm{~nm})$ and vertical wind variance, which is proportional to the amount of turbulent kinetic energy and indicates the strength of the mixing process. Table 8 contains characteristic values of these parameters for all days of the campaign including temperature. In agreement with the results presented by Boy and Kulmala (2002b) for 


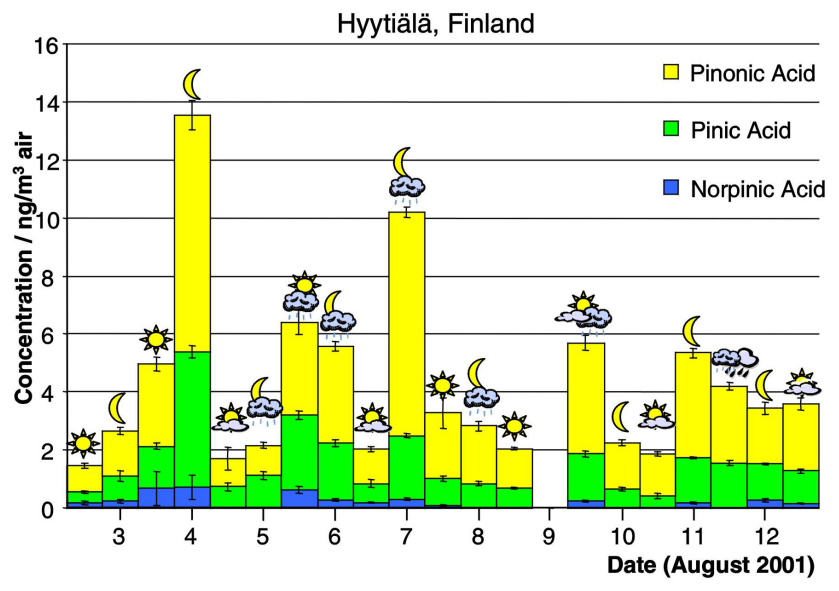

Fig. 14. Acids of biogenic origin quantified in samples from Hyytiälä, Finland. The symbols are indicating the meteorological conditions during the sampling period.

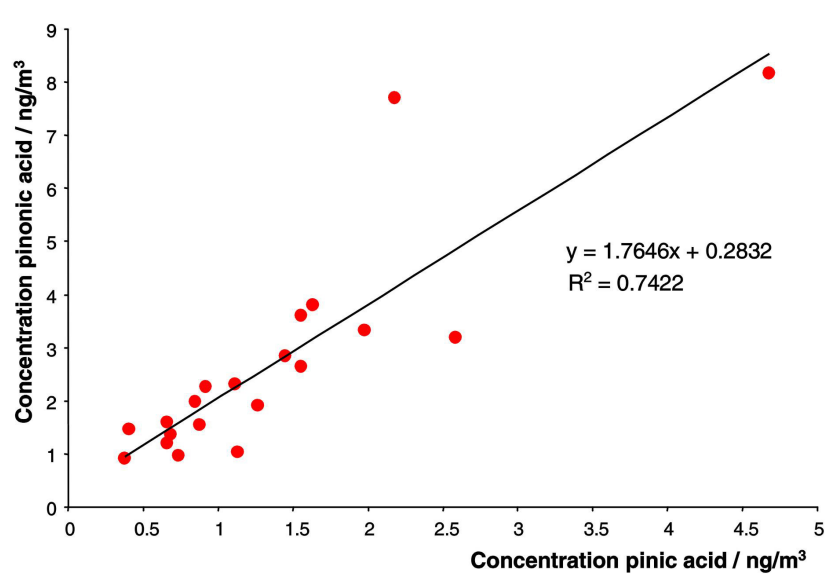

Fig. 15. Concentration of pinic acid vs. pinonic acid in atmospheric aerosol samples.

a one-year data analysis at Hyytiälä, Finland the relative humidity is lower during periods of particle bursts or decreases in front of the nucleation onset. The same result concerning the influence of water molecules was investigated by Bonn et al. (2002) in laboratory experiments: ozonolysis of monoterpenes and especially of exocyclic monoterpenes $(\beta$-pinene and sabinene).

According to Boy and Kulmala (2002a) we choose short wavelength irradiance $\left(\mathrm{E}_{S}\right)$ measured with a radiospectrometer as the determinant radiation factor in this analysis. All event days show roughly the same behaviour with the appearance of the particle bursts after $\mathrm{E}_{s}>6 \mathrm{~W} \mathrm{~m}^{-2}$. If we include in our consideration the time a new cluster needs to grow to the detectable size of $3 \mathrm{~nm}$ (approximately $20 \mathrm{~min}$ with the growth rates from Table 2 - thin black line in Fig. 17) then the nucleation would start at all event days during the ascending part of the irradiance curve. Furthermore these estimated

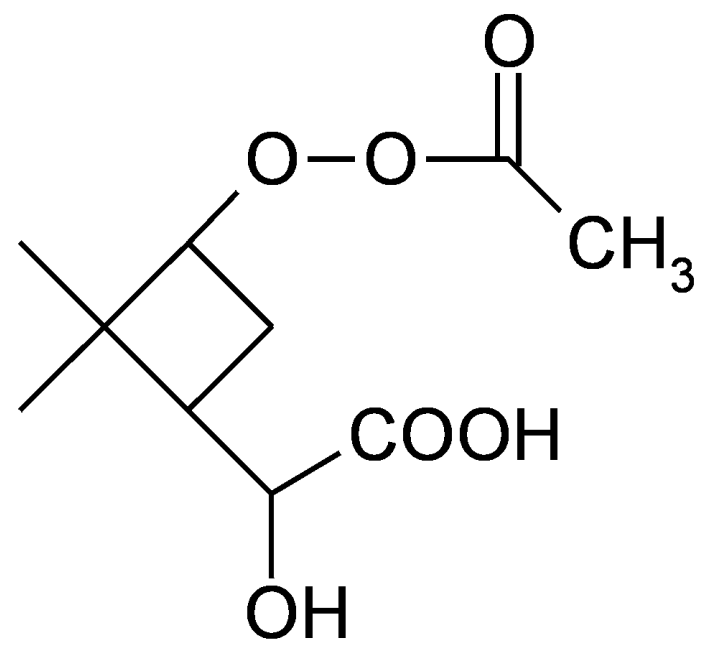

Fig. 16. Structure of " $\mathrm{m} / \mathrm{z} 231$ "
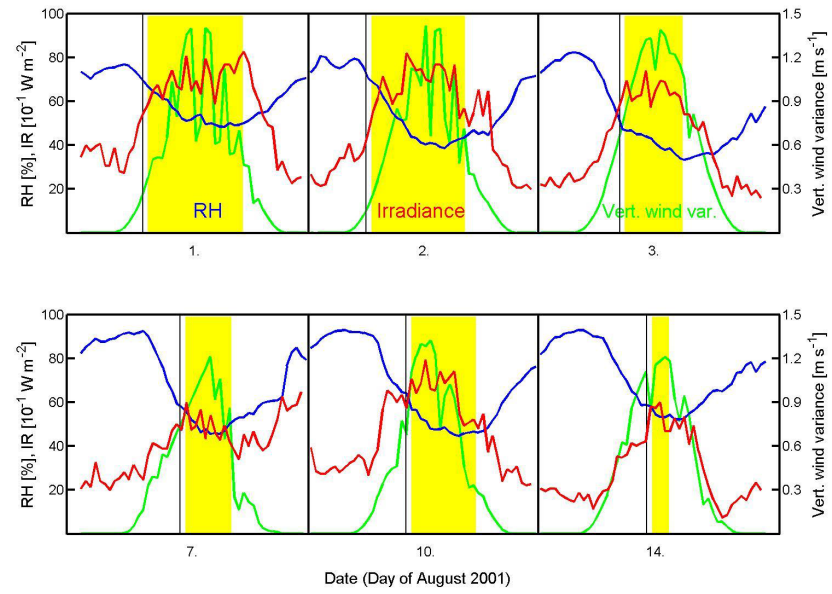

Fig. 17. Half hour average values of relative humidity, solar short wavelength irradiance $(300-340 \mathrm{~nm})$ and vertical wind variance. The yellow area marks the periods when bursts of nucleation mode particles were observed.

nucleation start times are coinciding with the onset of vertical wind variance and so the start of mixing different air masses from the residual and the surface layer.

In the end we will also include the temperature in our considerations. Although the solar radiation reaches higher values during the first three days of August compared to the rest of the campaign the diurnal mean values of the temperature especially on the 1 st and 2 nd of August are about $5 \mathrm{~K}$ lower than on the other days. Without analysing any weather maps we can conclude that relatively clean and cold air from northwest passed over the station during this period (see Figs. 2, 6 and 10). According to Nilsson et al. (2001a) nucleation in Hyytiälä occurs in arctic and to some extent in polar air masses, with a preference for air in transition from marine to continental air masses. The results from Nilsson et al. 
Table 8. Characteristic values from relative humidity, vertical wind variance, temperature and short wavelength irradiance (300-340 nm).

\begin{tabular}{lcccccccc}
\hline \multirow{2}{*}{ Date } & \multicolumn{2}{c}{$\mathrm{RH}(\%)$} & \multicolumn{2}{c}{ Vert. wind variance $\left(\mathrm{m} \mathrm{s}^{-1}\right)$} & \multicolumn{2}{c}{ Irradiance $\left(\mathrm{W} \mathrm{m}^{-2}\right)$} & \multicolumn{2}{c}{ Temp. $\left({ }^{\circ} \mathrm{C}\right)$} \\
& Mean & Min. & Mean & Max. & Mean & Max. & Mean & Max. \\
\hline 1 Aug. & 55.3 & 48.3 & 1.01 & 1.24 & 5.0 & 9.3 & 13.4 & 14.7 \\
2 Aug. & 48.6 & 38.8 & 0.97 & 1.23 & 5.0 & 9.4 & 11.8 & 13.7 \\
3 Aug. & 44.8 & 33.3 & 0.84 & 1.11 & 5.9 & 9.2 & 14.7 & 18.0 \\
4 Aug. & 61.9 & 48.1 & 0.95 & 1.37 & 3.8 & 7.6 & 15.4 & 17.6 \\
5 Aug. & 77.5 & 54.0 & 0.64 & 1.00 & 4.1 & 8.6 & 17.9 & 20.8 \\
6 Aug. & 76.1 & 56.9 & 0.50 & 0.83 & 3.2 & 7.5 & 15.5 & 17.8 \\
7 Aug. & 61.1 & 45.4 & 0.64 & 0.90 & 4.2 & 8.1 & 16.6 & 18.8 \\
8 Aug. & 57.8 & 43.9 & 0.73 & 1.01 & 4.9 & 8.7 & 16.9 & 19.1 \\
9 Aug. & 73.0 & 52.7 & 0.78 & 1.03 & 3.1 & 7.0 & 17.3 & 20.4 \\
10 Aug. & 58.9 & 44.8 & 0.88 & 1.19 & 4.7 & 8.8 & 17.3 & 19.1 \\
11 Aug. & 81.6 & 56.3 & 0.49 & 0.79 & 2.2 & 6.9 & 13.8 & 17.8 \\
12 Aug. & 75.8 & 60.9 & 0.60 & 0.85 & 3.2 & 7.8 & 14.3 & 16.2 \\
13 Aug. & 76.8 & 58.3 & 0.56 & 0.89 & 3.3 & 8.0 & 15.2 & 17.9 \\
14 Aug. & 63.8 & 52.2 & 0.59 & 0.90 & 4.8 & 8.1 & 15.8 & 18.5 \\
15 Aug. & 62.7 & 48.2 & 0.65 & 0.86 & 4.8 & 7.8 & 19.4 & 22.4 \\
16 Aug. & 73.0 & 47.9 & 0.75 & 1.07 & 3.9 & 7.9 & 19.9 & 24.0 \\
\hline
\end{tabular}

established during BIOFOR campaign in Hyytiälä, Finland agree completely with the first three events. However the other event days show different meteorological situations.

\section{Summary and conclusions}

The main results of the OSOA field campaign are described in Sect. 3. Obviously two different kinds of meteorological situations appeared during this period. In the beginning of August (1 to 3 ) clean cold air masses - nucleation favouring conditions - from northwest passed over the station (low values of $\mathrm{NO}_{\mathrm{x}}, \mathrm{SO}_{2}$ and $\mathrm{CS}$ ). During these days clear particle formation events with number concentrations between 600 and 1200 particles $\mathrm{cm}^{-3}$ for nucleation mode particles (3$10 \mathrm{~nm}$ ) were observed. Later in August the dominating wind sector was south to east and the above mentioned parameters increased clearly. Still we observed three days with indications of particle bursts during this period. However, $14 \mathrm{Au}-$ gust is difficult to declare: event or pollution. All parameters calculated in Sect. 3.1.2 (growth rate, vapour concentration, vapour source and formation rate) are 4 to 5 times higher than during other event days and a clear peak in $\mathrm{NO}_{\mathrm{x}}$ between the formation start and end was measured. Furthermore, the particle number concentrations of nucleation mode particles and total particle number $(3-500 \mathrm{~nm})$ show the same ascent with a peak at $1.15 \mathrm{p} . \mathrm{m}$. of 1250 and 11000 particle $\mathrm{cm}^{-3}$, respectively. These results point more to the conclusion, that polluted air masses probably from the station building or the town of Tampere were transported over the measuring site on this day.
The analysis of precursor measurements, from Sect. 3.2 showed an opposite trend for the sum of terpenes from the number concentration of the nucleation mode particles. However, the high variation in the temporal coverage and the large scattering of the measurements during single days limit final conclusions. Nevertheless, a direct correlation between the concentration of monoterpenes and the ongoing of nucleation can be excluded. The same result is valid for the concentrations of the carboxylic acids, the photo-oxidation products from monoterpenes with the lowest saturation vapour pressures (Sects. 3.2.3 and 3.3). In this case, the highest concentrations of formic and acetic acids were measured between 4 and 13 August, excluding the three clear event days in the beginning of August. Further, the sum of gas- and particle-phase concentrations of nor-pinonic or pinonic acids measured during the first eight days in August leads to the same result. Summarising this paragraph brings the conclusion, that at least during the time of the campaign the concentrations of the supposed precursors and the condensing species aren't limiting factors for the formation of new particles in Hyytiälä, Finland. This fact is also supported by comparing the calculated vapour concentrations of the condensing species from Sect. 3.1.2 with the measurements. For the first five events we calculated necessary concentrations for the condensing species between $8-1510^{7}$ molecules $\mathrm{cm}^{-3}$ and the measured concentration of e.g. pinonic acid was during the first 3 event days below detection limit up to 3.6 $10^{6}$ molecules $\mathrm{cm}^{-3}$. However, the measured values are results of 12-h-sampling periods and we know that the reaction of $\mathrm{OH}$ radicals with monoterpenes is one important production path way for the carboxylic acids. So the concentrations of single diacid or mono-acid molecules will be much higher 
around noon than the 12-h average values. Including all carboxylic acids in our considerations gives the conclusion that their concentrations would be high enough to fulfil the role of the condensing species on the thermodynamically stable clusters during the time of particle bursts.

The chemical analyses, discussed in Sects. 3.3 and 3.4 of $\mathrm{PM}_{2}$ to $\mathrm{PM}_{10}$ particles done by four institutes independently with different sampling and analytical methods and the results of the HTDMA and OTDMA measurements from Sect. 3.1.3 gave the following results:

- the fraction of secondary organic carbon reaches $19 \%$ of the particle material on average with maxima during daytimes, which obviously indicates local or regional formation of secondary organic aerosols;

- the concentrations of the identified carboxylic acids (formic, acetic, pinonic, pinic, norpinic, sabinic, limonic and caric acids) reached values of up to $62 \mathrm{ng} \mathrm{m}^{-3}$;

- the formic to acetic ratio varied from 1.04 to 1.43 , thus indicating predominance of formic acid in the forested area of Hyytiälä. Formic acid is the main product of isoprene and monoterpenes oxidation by ozone, whereas acetic acid comes from direct emission from vegetation and partly from biomass burning and/or anthropogenic emissions;

- the calculated carbon preference indexes (CPI) for the whole range (C16-C34) gave values for the n-alkanes, n-alkanols and n-monocarboxylic acids of $2.69 \pm 1.0$, $8.52 \pm 4.16$ and $6.86 \pm 1.67$, respectively, where a CPI number higher than 3 indicates a major incorporation of recent biological constituents into the aerosol sample;

- the average growth factors in ethanol vapour and in water vapour for $100 \mathrm{~nm}$ particles show a diurnal variation with maxima during daytime;

- the ratio of 50 and $100 \mathrm{~nm}$ particles in ethanol and water vapours $(\sim 1.05$ and $\sim 0.85$, respectively) during the three clear events in the beginning of August indicate that the smaller particles contain a somewhat higher fraction of organic materials and a somewhat lower fraction of inorganic salts.

Summarising these points we recognise a clear contribution of organic matter originating from the oxidation of terpenes from the local biosphere to the sampled aerosols. However, the fact that current state-of-the-art techniques are not able to analyse nucleation mode particles separately still leaves a lack of information about the composition of these newly formed particles and to what extent the species with the lowest volatility (dicarboxylic acids) are responsible for the growth of the newly formed clusters.
One question still not answered concerning the formation of SOA is: "Where in the PBL are the particles formed?" The analysis of particle flux measurements indicates that during all formation events the dominating fluxes were downward. However, high uncertainties in this data set as mentioned in Sect. 3.1.4 and zero or even small upward fluxes during some event days prevent direct conclusions. Furthermore the vertical profiles of monoterpene concentrations showed as expected for gases with only ground-sources the highest values in the surface layer and the vertical profiles of aerosols in the PBL give some indications that the formation of newly formed particles is homogenous in the PBL (see Sect. 3.1.5). Summarizing, the question could not be answered in the frame of this project. However, we can assume that the particles are formed throughout PBL and different parameters such as temperature, humidity, solar irradiance and concentration of different gases like monoterpenes, $\mathrm{SO}_{2}$ or $\mathrm{OH}$ with varying vertical profiles shift the maxima of the particle formation rate to different height levels. To gain detailed information about this mechanism we would need vertical profiles of aerosols throughout the day with size and number distributions and simultaneous measurements of concentrations of different gas species.

Acknowledgements. The OSOA team acknowledges the financial support from the European Commission under contract EVK2CT-1999-00016 (OSOA). We thank the "Fundação para a Ciência e a Tecnologia" for financial support through the grant PRAXIS XXI/BD/18450/98 to A. Carvalho. The Ministry of Education of Greece (Herakleitos-EPEAEK Program) is acknowledged for financial support to M. Apostolaki. We would also like to thank the personnel of the SMEAR II station and the Hyytiälä Forestry Field Station for their help and support during the campaign.

Edited by: U. Baltensperger

\section{References}

Aalto, P., Hämeri, K., Becker, E., Weber, R., Salm, J., Mäkelä, J., Hoell, C., O'Dowd, C. D., Karlsson, H., Hansson, H.-C., Väkevä, M., Koponen, I., Buzoius, G., and Kulmala, M.: Physical chracterization of aerosol particles during nucleation events, Tellus, 35B, 344-358, 2001.

Abas, M. R. B. and Simoneit, B. R. T.: Composition of extractable organic matter of air particles from Malaysia: initial study, Atmos. Environ., 15, 2779-2793, 1996.

Alves, C., Carvalho, A., and Pio, C.: Mass balance of organic carbon fractions in atmospheric aerosols, J. Geophys. Res., 107, (D21), 8345-8354, 2002.

Alves, C., Pio, C., and Duarte, A.: Composition of extractable organic matter of air particles from rural and urban Portuguese areas, Atmos. Environ., 35, 5485-5496, 2001.

Birmili, W., Berresheim, H., Plass-Dülmer, C., Elste, T., Gilge, S., Wiedensohler, A., and Uhrner, U.: The Hohenpeissenberg aerosol formation experiment (HAFEX): a long-term study including size-resolved aerosol, $\mathrm{H}_{2} \mathrm{SO}_{4}, \mathrm{OH}$ and monoterpenes measurements, Atmos. Chem. Phys., 3, 361-378, 2003. 
Bonn, B., Schuster, G., and Moortgat G. K.: Influence of water vapour on the process of new particle formation during monoterpene ozonolysis, J. Phys. Chem. A, 106, (12), 2869-2881, 2002.

Boy, M. and Kulmala, M.: The part of the solar spectrum with the highest influence of the formation of SOA in the continental boundary layer, Atmos. Chem. Phys., 2, 375-386, 2002a.

Boy, M. and Kulmala, M.: Nucleation events in the continental boundary layer: Influence of physical and meteorological parameters, Atmos. Chem. Phys., 2, 1-16, 2002b.

Buzorius, G., Rannik, Ü., Mäkelä, J. M., Keronen, P., Vesala, T., and Kulmala, M.: Vertical aerosol fluxes measured by the eddy covariance method and deposition of nucleation mode particles above a Scots pine forest in southern Finland, J. Geophys. Res., 105, 19905-19916, 2000.

Buzorius, G.: Cut-off sizes and time constants of the CPC TSI 3010 operating at 1-3 lpm flow rates, Aerosol Sci. Technol., 35, 577$585,2001$.

Buzorius, G., Rannik, Ü., Nilsson, D., and Kulmala, M.: Vertical fluxes and micrometeorology during aerosol particle formation events, Tellus, 53B, 394-405, 2001.

Carvalho, A., Pio, C., and Santos, C.: Water-soluble hydroxylated organic compounds in German and Finnish aerosols, Atmos. Environ., 37, (13), 1775-1783, 2003.

Castro, L., Pio, C., Harrison, R., and Smith, D.: Carbonaceous aerosol in urban and rural European atmospheres: Estimation of secondary organic carbon concentrations, Atmos. Environ., 33, 2771-2781, 1999.

Chebbi, A. and Carlier, P.: Carboxylic acids in the troposphere, occurrence, sources and sinks: A review, Atmos. Environ., 30, 4233-4249, 1996.

Chow, J. C., Watson, J. G., Fujita, E. M., Lu, Z. Q., Lawson, D. R., and Ashbaugh, L.: Temporal and spatial variations of $\mathrm{PM}_{2.5}$ and $\mathrm{PM}_{10}$ aerosol in Southern California Air Quality Study, Atmos. Environ., 28, 2061-2080, 1994.

Christoffersen, T. S., Hjorth, J., Horie, O., Jensen, N. R., Kotzias, D., Molander, L. L., Neeb, P., Ruppert, L., Winterhalter, R., Virkkula, A., Wirtz, K., and Larsen, B. R.: Cis-Pinic acid, a possible precursor for organic aerosol formation from ozonolysis of a-pinene, Atmos. Environ., 32, 1657-1661, 1998.

Dal Maso, M., Kulmala, M., Lehtinen, K. E. J., Mäkelä, J. M., Aalto, P., and O'Dowd, C. D.: Condensation and coagulation sinks and formation of nucleation mode particles in coastal and boreal forest boundary layers, J. Geophys. Res., 107, (D19), 8097-9008, 2002.

Davis, K. J., Lenschow, D. H., and Zimmerman, P. R.: Biogenic Nonmethane Hydrocarbon Emissions Estimated from Tethered Balloon Observations, J. Geophys. Res., 99, (D12), $25587-$ 25 598, 1994.

Greenberg, J., Lee, B., Helmig, D., and Zimmerman, P.: Fully automated gas chromatograph-flame ionization detector system for the in situ determination of atmospheric non-methane hydrocarbons at low parts per trillion concentration, J. Chromotography, 676, 389-398, 1995.

Greenberg, J. P., Guenther, A., Zimmerman, P., Baugh, W., Geron, C., Davis, K., Helmig, D. and Klinger, L. F.: Tethered balloon measurements of biogenic VOCs in the atmospheric boundary layer, Atmos. Environ., 33, (6), 855-867, 1999.

Guenther, A., Hewitt, C. N., Erickson, D., Fall, R., Geron, C., Graedel, T., Harley, P., Klinger, L., Lerdau, M., McKay, W. A.,
Pierce, T., Scholes, B., Steinbrecher, R., Tallamraju, R., Taylor, J., and Zimmerman, P.: A global model of natural volatile organic compound emissions, J. Geophys. Res., 100, 8873-8892, 1995.

Guenther, A., Baugh, W., Davis, K., Hampton, G., Harley, P., Klinger, L., Vierling, L., Zimmerman, P., Allwine, E., Dilts, S., Lamb, B., Westberg, H., Baldocchi, D., Geron, C., and Pierce, T.: Isoprene fluxes measured by enclosure, relaxed eddy accumulation, surface-layer gradient, mixed-layer gradient, and mass balance techniques, J. Geophys. Res., 101, 18 555-18 568, 1996.

Hämeri, K., Koponen, I. K., Aalto, P., and Kulmal, M.: The particle detection efficiency of the TSI-3007 condensation particle counter, J. Aerosol Sci., 33, 1463-1469, 2002.

Hämeri, K., Väkevä, M., Aalto, P., Kulmala, M., Swietlicki, E., Zhou, J., Seidl, W., Becker, E., and O'Dowd C.: Hygroscopic and ccn properties of aerosol particles in boreal forests, Tellus, 53B, 359-379, 2001.

Hämeri, K., Väkevä, M., Hansson, H. C., and Laaksonen, A.: Hygroscopic growth of ultrafine ammonium sulphate aerosol measured using an ultrafine tandem differential mobility analyser, J. Geophys. Res., 105, 22 231-22 242, 2000.

Helmig, D., Balsley, B., Davis, K., Kuck, L. R., Jensen, M., Bognar, J., Smith Jr., T., Arrieta, R. V., Rodríguez, R., and Birks, J. $\mathrm{W}$ : Vertical profiling and determination of landscape fluxes of biogenic nonmethane hydrocarbons within the planetary boundary layer in the Peruvian Amazon, J. Geophys. Res., 103, (D19), 25 519-25 532, 1998.

Hoffmann, T., Odum, J. R., Bowman, F., Collins, D., Klockow, D., Flagan, R. C., and Seinfeld, J. H.: Formation of organic aerosols from the oxidation of biogenic hydrocarbons, J. Atmos. Chem., 26, 189-222, 1997.

Hoppel, W., Fitzgerald, J., Frick, G., Caffrey, P., Pasternack, L., Hegg, D., Gao, S., Leaitch, R., Shantz, N., Cantrell, C., Albrechcinski, T., Ambrusko, J., and Sullivan, W.: Particle formation and growth from ozonolysis of $\alpha$-pinene, J. Geophys. Res., 106, (D21), 27 603-27 618, 2001.

Joutsensaari, J., Vaattovaara, P., Vesterinen, M., Hämeri, K., and Laaksonen, A.: A novel tandem differential mobility analyzer with organic vapour treatment of aerosol particles, Atmos. Chem. Phys., 1, 51-60, 2001.

Kavouras, I., Mihalopoulos, N., and Stephanou, E. G.: Formation of atmospheric particles from organic acids produced by forests, Nature, 395, 683-686, 1998.

Kavouras, I., Mihalopoulos, N., and Stephanou, E. G.: Formation and Gas/Particle Partitioning of Monoterpenes Photo-oxidation Products over Forests, Geophys. Res. Lett., 26, (1), 55-58, 1999a.

Kavouras, I., Mihalopoulos, N., and Stephanou, E. G.: Secondary aerosol formation vs. primary organic aerosol emission: In situ evidence for the chemical coupling between monoterpene acidic photo-oxidation products and new particle formation over forests, Environ. Sci. Technol., 33, 1028-1037, 1999b.

Kawamura, K., Ng, L.-L., and Kaplan, I. R.: Determination of organic acids $(\mathrm{C} 1-\mathrm{C} 10)$ in the atmosphere, motor exhausts, and engine oils, Environ. Sci. Technol., 19, 1082-1086, 1985.

Kawamura, K. and Gagosian R. B.: Implication of w-oxocarboxylic acids in the remote marine atmosphere for photo-oxidation of unsaturated fatty acids, Nature, 325, 330-332, 1987.

Kirchstetter, T. W. and Novakov, T.: Differences in the volatility 
of oganic aerosols in unpolluted tropical and polluted continental atmospheres, J. Geophys. Res., 105, (D21), 26547-26 554, 2000.

Kirchstetter, T. W., Corrigan, C. E., and Novakov, T.: Laboratory and field investigation of the adsorption of gaseous organic compounds onto quartz filters, Atmos. Environ., 35, 1663-1671, 2001.

Koch, S., Winterhalter, R., Uherek, E., Kolloff, A., Neeb, P., and Moortgat, G.: Formation of new particles in the gas-phase ozonolysis of monoterpenes, Atmos. Environ., 32, 4031-4042, 2000.

Korhonen, P., Kulmala, M., Laaksonen, A., Viisanen, Y., McGraw, R., and Seinfeld, J. H.: Ternary nucleation of $\mathrm{H}_{2} \mathrm{SO}_{4}, \mathrm{NH}_{3}$ and $\mathrm{H}_{2} \mathrm{O}$ in the atmosphere, J. Geophys. Res., 104, 26349-26353, 1999.

Kulmala, M., Pirjola, L., and Mäkelä, J. M.: Stable sulphate clusters as a source of new atmospheric particles, Nature, 404, 66-69, 2000 .

Kulmala, M., Hämeri, K. K., Aalto, P., Mäkelä, J., Pirjola, L., Nilsson, E. D., Buzorius, G., Rannik, Ü., Dal Maso, M., Seidl, W., Hoffmann, T., Jansson, R., Hansson, H.-C., O`Dowd, C., and Viisane, Y.: Overview of the international project on biogenic aerosol formation in the boreal forest (BIOFOR), Tellus, 53B, 324-343, 2001a.

Kulmala, M., Dal Maso, M., Mäkelä, J. M., Pirjola, L., Väkevä, M., Aalto, P., Miikkulainen, P., Hämeri, K., and O'Dowd, C.: On the formation, growth and composition of nucleation mode particles, Tellus, 53B, 479-490, 2001b.

Lawrence, J. E. and Koutrakis, P.: Measurement of atmospheric formic and acetic acids: Methods evaluation and results from field studies, Environ. Sci. Technol., 28, 957-964, 1994.

Lawrence, J. and Koutrakis, P.: Measurement and speciation of gas and particulate phase organic acidity in an urban environment, I. Analytical, J. Geophys. Res., 101, 9159-9163, 1996.

Mihalopoulos, N., Stephanou, E. G., Kanakidou, M., Pilitzidis, S., and Bousquet, P.: Tropospheric aerosol ionic composition in the Eastern Mediterranean region, Tellus, 49B, 314-326, 1997.

Nilsson, E. D., Paatero, J., and Boy, M.: Effects of air masses and synoptic weather on aerosol formation in the continental boundary layer, Tellus, 53B, 462-478, 2001a.

Nilsson, E. D., Rannik, Ü., Kulmala, M., Buzorius, G., and O'Dowd, C. D.: Effects of continental boundary layer evolution, convection, turbulence and entrainment, on aerosol formation, Tellus, 53B, 441-461, 2001b.

Novakov, T., Hegg, D. A., and Hobbs, P. V.: Airborne measurements of carbonaceous aerosols on the East Coast of the United States, J. Geophys. Res., 102, 30 023-30 030, 1997.

Petäjä, T., Aalto, P., and Hämeri, K.: Hygroscopicity of toluene oxidation products, Abstracts of the Sixth International Aerosol Conference in Taipei, 851-852, 2002.

Peters, K. and Eiden, E.: Modelling of the dry deposition velocity of aerosol particles to a spruce forest, Atmos. Environ., 26A, 25552564, 1992

Pio, C., Castro, L., and Ramos, M.: Differentiated determination of organic and elemental carbon in atmospheric aerosol particles by a Thermal-optical method, edited by Angeletti, G. and Restelli, G., Proc. Sixth European Symp. on Physico-chemical Behaviour of Atmospheric Pollutants, Report EUR 15609/2 EN, 706-711, 1994.
Rinne, J., Hakola, H., Laurila, T., and Rannik, Ü.: Canopy scale monoterpene emissions of Pinus sylvestris dominated forests, Atmos. Environ., 34, 1099-1107, 2000.

Römpp, A. and Moortgat, G.: Analysis of Oxygenated Compounds in Ambient Aerosol by LC-MS-TOF, Proceedings of EUROTRAC 2002 Symposium, 2002.

Rogge, W. F., Hildemann, L. M., Mazurek, M. A., Cass, G. R., and Simoneit, B. R. T.: Sources of fine organic aerosol, 1. Charbroilers and meat cooking operations, Environ. Sci. Technol., 25, 1112-1125, 1991

Simoneit, B. R. T.: Organic matter of the troposphere - V: Application of molecular analysis to biogenic emissions into the troposphere for source reconciliations, J. Atmos. Chem., 8, 251-275, 1989.

Simoneit, B. R. T.: Biomass burning - a review of organic tracers for smoke from incomplete combustion, Applied Geochemistry, 17, 129-162, 2002

Simoneit, B. R. T., Cox, R. E., and Standley, L. J.: Organic matter of the troposphere-IV, Lipids in Harmattan aerosols of Nigeria, Atmos. Environ., 22, 983-1004, 1988.

Simoneit, B., Schauer, J., Nolte, C., Oros, D., Elias, V., Fraser, M., Rogge, W., and Cass, G.: Levoglucosan, a tracer for cellulose in biomass burning and atmospheric particles, Atmos. Environ., 33, 173-182, 1999.

Standley, L. and Simoneit, B. R. T.: Characterization of extractable plant wax, resin, and thermally maturated components in smoke particles from prescribed burns, Environ. Sci. and Technol., 21, 163-169, 1987.

Standley, L. and Simoneit, B. R. T.: Resin diterpenoids as tracers for biomass combustion aerosols, J. Atmos. Chem., 18, 1-15, 1994.

Stephanou, E. and Stratigakis, N.: Determination of anthropogenic and biogenic organic compounds on airborne particles: flash chromatographic fractionation and capillary gas chromatographic analysis, J. Chromatogr. A, 644, 141-151, 1993.

Sirju, A.-P. and Shepson, P. B.: Laboratory and field investigation of the DNPH cartridge technique for measurement of atmospheric carbonyl compounds, Environ. Sci. Technol., 29, 384-392, 1995.

Stratman, F., Siebert, H., Spindler, G., Wehner, B., Althausen, D. Heintzenberg, J., Hellmuth, O., Rinke, R., Schmieder, U., Seidel, C., Tuch, T., Uhrner, U., Wiedensohler, A., Wandinger, U., Wendisch, M., Schell, D., and Stohl, A.: New-particle formation events in a continental boundary layer: First results from the SATURN experiment, Atmos. Chem. Phys., 3, 1445-1459, 2003.

Talbot, R. W., Beecher, K. M., Harris, R. C., and Coferr, W. R. III Jr.: Atmospheric chemistry of formic and acetic acids at a midlatitude temperate site, J. Geophys. Res., 93, 1638-1652, 1988.

Virkkula, A., Van Dingenen, R., Raes, F., and Hjort, J.: Hygroscopic properties of aerosol formed by oxidation of limonene, alpha-pinene, and beta-pinene, J. Geophys. Res., 104, 35693579, 1999.

Warscheid, B. and Hoffmann, T.: Direct analysis of highly oxidised organic aerosol constituents by on-line ion trap mass spectrometry in the negative ion mode, Rapid. Commun. Mass Spectrom., 16, 496-504, 2002

Winklmayr, W., Reischl, G., Lindner, A., and Berner, A.: A new electromobility spectrometer for the measurement of aerosol size distributions in the size range from 1 to $1000 \mathrm{~nm}$, J. Aerosol Sci., 22, 289-296, 1991 
Winterhalter, R., Neeb, P., Grossmann, D., Kolloff, A., Horie, O., and Moortgat, G.: Products and mechanism of the gas phase reaction of ozone with b-pinene, J. Atmos. Chem., 35, 165-197, 2000.

Yokouchi, Y. and Ambe, Y.: Aerosols formed from the chemical reaction of monoterpenes and ozone, Atmos. Environ., 19, 12711276, 1985.
Yokouchi, Y. and Ambe, Y.: Characterization of polar organics in airborne particulate matter, Atmos. Environ., 20, 1727-1734, 1986.

Zervas, E., Montagne, X., and Lahaye, J.: Collection and analysis of organic acids in exhaust gas, Comparison of different methods, Atmos. Environ., 33, 4953-4962, 1999. 